\title{
The Structure of Tariffs and Long-Term Growth
}

\section{Citation}

Nunn, Nathan, and Daniel Trefler. 2010. "The Structure of Tariffs and Long-Term Growth." American Economic Journal: Macroeconomics 2 (4) (October): 158-194. doi:10.1257/ mac.2.4.158. http://dx.doi.org/10.1257/mac.2.4.158.

\section{Published Version}

doi:10.1257/mac.2.4.158

\section{Permanent link}

http://nrs.harvard.edu/urn-3:HUL.InstRepos:11986329

\section{Terms of Use}

This article was downloaded from Harvard University's DASH repository, and is made available under the terms and conditions applicable to Other Posted Material, as set forth at http:// nrs.harvard.edu/urn-3:HUL.InstRepos:dash.current.terms-of-use\#LAA

\section{Share Your Story}

The Harvard community has made this article openly available.

Please share how this access benefits you. Submit a story.

Accessibility 


\title{
The Structure of Tariffs and Long-Term Growth
}

\author{
By Nathan Nunn and Daniel TrefleR*
}

\begin{abstract}
We show that the "skill bias" of a country's tariff structure is positively correlated with long-term per capita GDP growth. Testing for causal mechanisms, we find evidence consistent with the existence of real benefits from tariffs focused in skill-intensive industries. However, this only accounts for a quarter of the total correlation between skill-biased tariffs and growth. Turning to alternative explanations, we extend the standard Grossman-Helpman "protectionfor-sale" model and show how the skill bias of tariffs can reflect the extent of domestic rent-seeking activities in the economy. We provide evidence that the remaining variation is explained by this endogeneity. (JEL D72, F13, F43, O17, O19, O24, O47)
\end{abstract}

T ariffs can create allocative inefficiencies that reduce national income. There is thus a legitimate presumption that high average levels of tariffs are a poor policy choice. However, tariffs can also be used to raise national income provided the appropriate industry is chosen for protection. Examples include Paul Krugman's (1987) model of learning-by-doing and Gene M. Grossman and Elhanan Helpman's (1991) endogenous growth models with research and development (R\&D) externalities. In these models, tariffs raise per capita gross domestic product (GDP) when they target the industry subject to externalities. Thus, while the average tariff matters, so too does the finer structure of tariffs across industries. Yet tariff structure has been entirely absent from the empirical tariffs-and-growth literature.

The current empirical literature examines the impact of a country's average tariff level on its subsequent long-term growth. For the post-war period, the impact of average tariffs on growth is found to be negative in Sebastian Edwards $(1992,1998)$ and Michael A. Clemens and Jeffrey G. Williamson (2004) and positive in Athanasios Vamvakidis (2002), Halit Yanikkaya (2003), and David N. DeJong and Marla Ripoll (2006). For the late-nineteenth century, the results are even more conflicting. See

* Nunn: Department of Economics, Harvard University, 1805 Cambridge Street, Cambridge, MA, 02138, and The National Bureau of Economic Research (NBER) and Bureau for Research and Economic Analysis of Development (BREAD) (e-mail: nnunn@fas.harvard.edu); Trefler: Rotman School of Management and Department of Economics, University of Toronto, 105 Saint George Street, Toronto, ON, M5S 3E6, and the Canadian Institute for Advanced Research (CIFAR), and NBER (e-mail: dtrefler@rotman.utoronto.ca). We thank two referees for comments that substantially improved the paper. We also thank Daron Acemoglu, Eugene Beaulieu, Elhanan Helpman, Torsten Persson, Manuel Trajtenberg, and Jeffrey Williamson, as well as seminar participants at the University of British Columbia, Korea University, Harvard University, Simon Fraser University, University of Toronto, World Bank, CEA Meetings, CIFAR's IOG Program Meetings, and the EIIT Conference. The Social Sciences and Humanities Research Council of Canada (SSHRC) and the CIFAR kindly provided funding for this project.

$\dagger$ To comment on this article in the online discussion forum, or to view additional materials, visit the articles page at http://www.aeaweb.org/articles.php?doi=10.1257/mac.2.4.158. 
Kevin H. O'Rourke (2000), Vamvakidis (2002), Clemens and Williamson (2004), and David S. Jacks (2006).

We enter the debate by examining the role of the cross-industry structure of tariffs. As a conceptual framework, we use the Grossman and Helpman (1991, chapter 8) variety-expansion model of endogenous growth. There is one homogenous good and a continuum of horizontally differentiated varieties. A new blueprint is required for each new variety, and the cost of this innovation is decreasing in the number of varieties already being produced in the country. There are thus national as opposed to international returns to scale. A tariff on the homogeneous good draws resources away from variety goods and R\&D (e.g., blueprint production), thus reducing per capita GDP. In contrast, there are parameter values for which a tariff on variety goods, by increasing the number of domestic varieties, can push the economy off a transition path in which the variety sector is in permanent decline and onto a transition path in which the country comes to dominate world production of variety goods. Along this latter transition path, output and per capita GDP rise. Further, once on this transition path the country stays on it even after the tariff is removed: there is path dependence.

With the model in hand, we empirically examine the role of tariff structure in a path-dependent world. To this end, we examine data for 63 developing and developed countries over roughly the 1972-2000 period. (The choice of countries is constrained by the availability of sectoral tariff data.) Empirically, we proxy for the $R \& D$ or innovation intensity of an industry using the ratio of the industry's skilled workers to its unskilled workers. We then calculate measures of the degree to which a country's tariff structure disproportionately favours its skill-intensive industries, which we refer to as the "skill bias" of the tariff structure. We regress long-term per capita GDP growth on the skill bias of tariffs, controlling for a large set of covariates that include detailed region fixed effects, initial production structure, per capita income, human capital, and investment. Our estimates reveal a strong, positive correlation between the skill bias of tariffs and long-term economic growth. We find the correlation to be extremely robust and economically very large.

Results based on cross-country growth regressions-including our own-can be difficult to interpret. For one, the results are often interpreted to mean that growth differentials can be sustained indefinitely, despite evidence to the contrary (e.g., William Easterly, et al. 1993). We make no such interpretation: our concern is with transition paths. For another, growth regressions uncover correlations, not causality or causal mechanisms. To gain traction on mechanisms, we introduce an industry dimension to our panel data. For each country and year we have data on gross output for 18 sectors (agriculture and manufacturing industries). The industry dimension allows us to directly test the causal mechanisms highlighted in our theoretical model. The theory implies that a skill-biased tariff distribution causes a differential expansion of skill-intensive industries, which is beneficial for long-term growth. We find evidence for the mechanism, but also find that it is unable to account for more than a quarter of the correlation between the skill bias of tariffs and long-term growth.

We then turn to alternative explanations for the correlation. Stepping outside of the model, protection of skill-intensive industries may generate economywide externalities. For example, it may raise the demand for human capital and 
innovation, which in turn may raise the incentives to invest in education and knowledge accumulation. However, when we add to our regressions country-level measures of the growth of human capital and knowledge (as measured by patents), these variables are jointly insignificant and do not alter the coefficient on the skill bias of tariffs. We find no evidence for these mechanisms.

Unable to find additional economic channels that can fully account for the importance of the skill bias of tariffs, we turn to political economy explanations which flow from the potential endogeneity of tariffs. Countries with good institutions may more heavily protect skill-intensive industries, and it may be the institutions, rather than tariff structure, that matters for growth (e.g., Paulo Mauro 1995; Robert E. Hall and Charles I. Jones 1999; Daron Acemoglu, Simon Johnson, and James A. Robinson, 2001). We motivate the link between rent-seeking and a skill-biased tariff structure by extending the Gene M. Grossman and Elhanan Helpman (1994) "protection-for-sale" model. Consistent with our first model, we consider an environment with positive externalities in skill-intensive industries. The government puts a weight $a$ on the welfare gains from these externalities. We interpret $a$ as a facet of institutions, a large $a$ being associated with good governance. We show that in the subgame perfect Nash equilibrium, the larger a country's $a$ the more it protects skillintensive industries relative to unskilled-intensive industries.

Turning to the data, we examine whether the correlation of growth with the skill bias of tariffs is weakened by controlling for standard measures of governance and institutions. We consider all six of the World Bank's measures of governance (David Kaufmann, Aart Kraay, and Massimo Mastruzzi 2003). By failing to include institutional measures in our regressions, we may have induced a spurious correlation between growth and the skill bias of tariffs. When we estimate a single regression that includes the skill bias of tariffs along with all six of the World Bank's measures of governance, the coefficient on the skill bias of tariffs shrinks by about 35 to 40 percent, but remains significant in all specifications.

The robustness of our correlation between growth and the skill bias of tariffs presents a potential puzzle. Real channels highlighted by our model of tariffs and growth are able to explain about 25 percent of the correlation. Omitted variablesbias, arising from the positive correlation between the skill bias of tariffs and standard measures of governance, explains another 35 percent. This leaves 40 percent of the correlation to be explained.

Our explanation appears in Section VIIB. Standard measures of governance, including the World Bank measures of governance, focus on corruption and constraints on illegal rent-seeking activities. Yet contributions in the protection-for-sale model are usually interpreted as legally and socially acceptable influence peddling. For example, both Pinelopi Goldberg and Giovanni Maggi (1999) and Kishore Gawande and Usree Bandyopadhyay (2000) measure influence peddling using publicly recorded political contributions. It appears that the remaining 40 percent of our correlation can be explained by purely legal and socially acceptable rent-seeking activities. This explanation is supported by the fact that the skill bias of tariffs is highly correlated with two new objective measures of purely legal, rent-seeking activities. These are Mara Faccio's (2006b) measure of political connections and Raymond Fisman and Edward Miguel's (2007) measure of diplomatic parking tickets. 
The outline of the paper is as follows. Section I reviews an economic model with externalities, path dependence, and tariffs. Sections II through IV report our first result: in a cross-country growth regression setting the skill bias of tariffs is positively correlated with long-term growth. Section V searches for causal mechanisms underlying this correlation by extending the empirics to the industry level. We find evidence consistent with the mechanism highlighted in our model of path-dependence, but the mechanism is unable to account for more than a quarter of the total correlation between skill bias of tariffs and growth. We also consider a number of other mechanisms outside of the model, but find no evidence for these. Having exhausted purely economic mechanisms, we then turn to explanations that focus on the endogeneity of tariff policies. Section VI provides a political economy "protection-for-sale" model that generates a positive correlation between good governance (large $a$ ) and skill-biased tariffs. Section VII argues that a skill-biased tariff structure captures something not previously found in the literature on governance and institutions-namely that legal, political, and social norms can constrain influence peddling and rent seeking.

\section{The Structure of Tariffs and the Growth Process}

We briefly review the model presented in chapter 8 of Grossman and Helpman (1991). There are two countries $(c=A, B)$. Each has a fixed supply of a single primary factor, labour $\left(L_{A}=L_{B}=L\right)$. Also, the countries share identical technologies. There are thus no traditional sources of comparative advantage.

$L$ is used in one of three constant-returns-to-scale sectors. The traditional sector produces a homogeneous good $z$, the "high-tech" sector produces horizontally differentiated varieties $i$ of a good $x$, and the R\&D sector develops the blueprints needed to produce a variety. There is no foreign direct investment so that blueprint development and $x$ production must co-locate. Blueprint development plays the role of a fixed cost. Units of each activity are chosen to make all three input coefficients equal to one.

Identical, infinitely lived consumers maximize utility $U_{t}=\int_{t}^{\infty} e^{-\rho(\tau-t)} \ln C(\tau) d \tau$ where

$$
\mathrm{C}(\tau) \equiv \sigma \ln \left[\int_{0}^{n_{\tau}} x(i)^{(\epsilon-1) / \epsilon} d i\right]^{\epsilon /(\epsilon-1)}+(1-\sigma) \ln z
$$

$n_{\tau}$ is the number of varieties available worldwide in period $\tau$ and $\rho, \sigma$ and $\epsilon$ are preference parameters. Savings are internationally mobile and nominal interest rates are equated across countries. ${ }^{1}$

Growth is driven by knowledge spillovers associated with the development of new blueprints and these spillovers are national in scope. The key feature of the model

\footnotetext{
${ }^{1}$ These savings are invested either in bonds or in equities issued by firms conducting R\&D. There is full information and no uncertainty so that returns on bonds and equities are equated. With the normalization that world expenditures equal one in each period, the nominal interest rate equals $\rho$. See Grossman and Helpman (1991, chapter 8) for details.
} 
is that producing a blueprint in country $c$ generates knowledge that makes it easier for other country- $c$ firms to develop blueprints. More formally, let $w_{c t}$ be the wage and $n_{c t}$ be the number of varieties produced in country $c$ in period $t$. Then the cost of producing a blueprint is assumed to be $w_{c t} / n_{c t}$. This assumption means that the initial distribution of varieties across countries $\left(n_{A 0}, n_{B 0}\right)$ is the only source of comparative advantage.

The basic dynamics of the model are as follows. Suppose that country $A$ initially produces more varieties than country $B$. Ignoring possible wage differentials for the moment, $A$ will be the low-cost location for R\&D. This leads in the next period to even more country- $A$ varieties and even lower country- $A$ R\&D costs. Thus, in any stable steady state all R\&D and all production of $x$ must be concentrated in a single country. Further, in all of the equilibrium transition paths that Grossman and Helpman (1991) characterize, $\mathrm{R} \& \mathrm{D}$ and $x$ production eventually come to be dominated by a single country.

Grossman and Helpman (1991) characterize, in detail, a set of transition paths that are particularly relevant for our paper. Consider a transition path in which initially $w_{A 0}>w_{B 0}, n_{A 0}>n_{B 0}$ and $w_{A 0} / n_{A 0}<w_{B 0} / n_{B 0}$. That is, country $A$ is rich and has a comparative advantage in $\mathrm{R} \& \mathrm{D}$, while country $B$ is poor and has a comparative advantage in producing the homogenous good $z$. Thus, $z$ is produced only in country $B$ and $x$ varieties are produced in both countries, though primarily in country $A$. Then there exists a transition path along which $w_{A t}$ is rising, $w_{B t}$ is falling, all new varieties are developed and produced in $A$, and $A$ 's share of world expenditures on $x$ approaches one. This implies that on the transition path welfare, per capita GDP, and output all grow faster in $A$ than in $B$.

Consider the impact of an R\&D subsidy by country $B$ that is large enough to make country $B$ the low-cost producer of blueprints. Now all new R\&D occurs in $B, n_{B t}$ rises, $B$ becomes an even more attractive location for $\mathrm{R} \& \mathrm{D}$, and eventually a time is reached when $B$ is the low-cost producer of blueprints even without the subsidy. That is, government policy has tipped the world onto a new transition path in which $A$ and $B$ switch roles. The reversal remains even if the subsidy is eliminated. In short, the model displays path dependence in which the initial subsidy, even if removed, leads to transition-path growth in welfare, per capita GDP, and output.

So far we have simply reviewed chapter 8 of Grossman and Helpman (1991). They do not consider a country- $B$ tariff on $x$, which is the focus of our empirical work. Such a tariff is similar to an R\&D subsidy, but has two additional effects. First, unlike the R\&D subsidy which is the first-best policy for addressing the R\&D externality, the tariff is a second-best policy that distorts consumer decisions. While this distortion cannot alter the fact that world $x$ production must eventually concentrate in a single country, it does mean that incomes will not grow as quickly. Second, the tariff creates another force pushing for agglomeration of $x$ production. This is a standard economic geography force, as in Masahisa Fujita, Krugman, and Anthony J. Venables (2001, chapter 4). In particular, the price index for varieties will no longer be the same in both countries. As $B$ develops relatively more varieties its price index falls relatively faster than $A$ 's price index, leading to higher welfare, real wages, and real per capita GDP in country $B$. Further, there will be a home-market effect that fosters agglomeration of the $x$ industry in country $B$. The price-index and home-market 
Table 1 -Countries Grouped by Geographic Region.

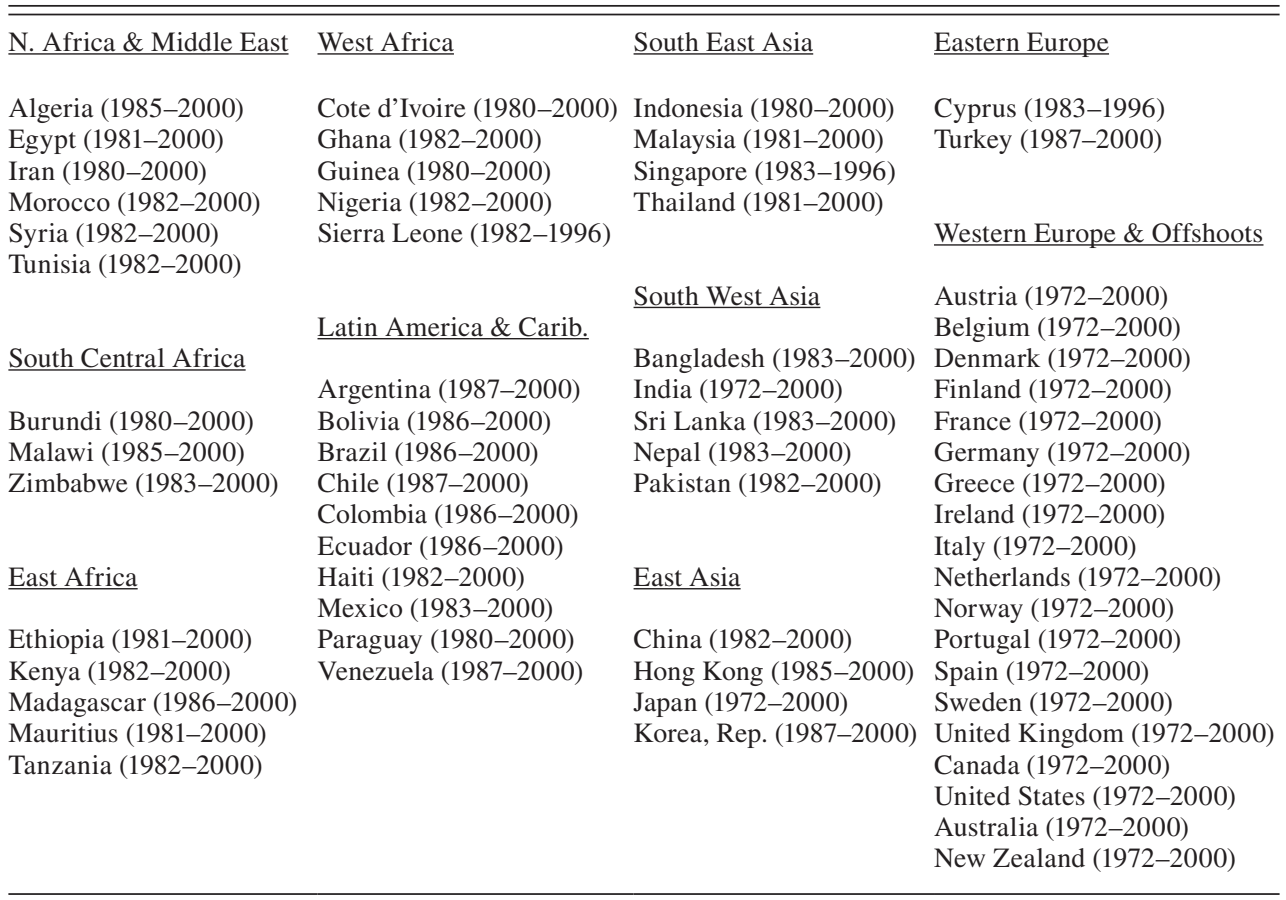

effects reinforce the path-dependent process already described in the context of an R\&D subsidy. In short, a tariff on $x$ promotes transition-path growth while a tariff on $z$ retards transition-path growth.

This theoretical discussion leads us to an empirical specification in which per capita GDP growth (on the transition path) is related to the initial structure of tariffs. Let $\ln y_{c 1} / y_{c 0}$ be average annual $\log$ growth in per capita GDP in country $c$. Let $S B \tau_{c 0}$ be a measure of how the initial cross-industry tariff structure of country $c$ is skewed towards the protection of externality generating R\&D-intensive sectors. In practice, we take an industry's skill-intensity as a proxy for R\&D intensity. We thus refer to $S B \tau_{c 0}$ as the skill bias of a country's tariffs.

Our country-level estimating equation is

$$
\ln y_{c 1} / y_{c 0}=\alpha+\beta_{S B} S B \tau_{c 0}+\mathbf{X}_{c 0} \beta_{X}+\varepsilon_{c} .
$$

As we outline in the following section, $\mathbf{X}_{c 0}$ includes standard controls for initial country characteristics from the cross-country growth literature. In addition, the model also provides guidance for an additional covariate that we must control for. In the model initial industrial structure is a source of comparative advantage, which in turns impacts long-term growth. Therefore, we are also careful to control for initial industrial structure when we introduce our skill-bias-of-tariff measures in Section IV. 


\section{Data Description and Average Tariffs}

The list of countries in our sample appears in Table 1. There are 63 countries. The choice of countries is primarily determined by the availability of industry-level tariff data. Tariff data are from Huiwen Lai and Daniel Trefler (2002) and the United Nations Conference on Trade and Development (UNCTAD) (1994), and production data is from the United Nations Industrial Development Organization (UNIDO) (2003). To match the Standard International Trade Classification (SITC) tariff data with International Standard Industrial Classification (ISIC) production data, we have aggregated the data up to a common set of 18 agricultural and manufacturing industries. Additional information about the data appears in Appendix B.

The availability of disaggregated tariff data is different for each country so that we are unable to use the same time period for all countries. For 21 countries tariffs are available beginning in 1972, for 30 countries tariffs are available beginning in the 1980-83 period and for 12 countries tariffs are available beginning in the 198587 period. See Table 1 for details. To control for the three different entry periods, we include cohort fixed effects in equation. ${ }^{2}$

We are interested in long-term growth of per capita GDP. Let $t_{c 0}$ denote the first year that country $c$ appears in the data. Let $t_{c 1}$ denote the last year that country $c$ appears in the data (usually 2000). Let $y_{c t}$ denote GDP per capita in year $t$ so that $\left(1 /\left(t_{c 1}-t_{c 0}\right)\right) \ln y_{c, t_{c 1}} / y_{c, t_{c 0}}$ is the average log change in per capita GDP over the duration of the data. At the risk of abusing notation, we will henceforth denote this average log change in per capita GDP more simply as $\ln y_{c 1} / y_{c 0}$. Per capita GDP data are from the Penn World Tables (PWT), Mark 6.1.

We begin by briefly presenting a standard regression of per capita GDP growth on average tariffs. This will show both that average tariffs are not important and will familiarize the reader with the details of the specification. Consider Table 2, which reports estimates of equation (1), but with initial average tariffs in place of the skill bias of tariff structure. The specification in column 1 includes cohort fixed effects. It also includes three standard initial country characteristics (log of initial per capita GDP, the log of initial human capital, and the log of the initial investment-to-GDP ratio). See Appendix B for data sources.

Turning to average tariffs, the log of average tariffs $\ln \bar{\tau}_{c 0}$ does not matter for longterm growth. The coefficient is statistically insignificant and economically small. This result contrasts with a growing literature on the effects of average tariffs on growth. The literature either finds significant negative effects (Edwards 1992, 1998; Clemens and Williamson 2004), significant positive effects (Vamvadikis 2002; Yanikkaya 2003), or both depending on the sample of countries (DeJong and Ripoll 2006). ${ }^{3}$

\footnotetext{
${ }^{2}$ The data end in 2000. However, in the country-level regressions there are three countries for which per capita GDP data end in 1996. These are Singapore, Cyprus, and Sierra Leone. Adding a 1996 cohort dummy to control for these early exits does not affect our results. Nor is the dummy statistically significant. We therefore omit it.

${ }^{3}$ In a related literature that looks at the relationship between "trade openness" broadly defined and growth, studies have tended to find a positive relationship between openness and growth, e.g., Jeffrey D. Sachs and Andrew Warner (1995). However, whether the openness measures used exclusively measure trade openness remains an unanswered question precisely because trade openness is correlated with institutions, e.g., Francisco Rodriguez and Dani Rodrik (2001).
} 
TAble 2-Results for Average Tariffs.

\begin{tabular}{|c|c|c|c|c|}
\hline & \multicolumn{2}{|c|}{ (1) } & \multicolumn{2}{|c|}{ (2) } \\
\hline & $\beta$ & $t$-statistic & $\beta$ & $t$-statistic \\
\hline $\begin{array}{l}\text { Tariff structure } \\
\quad \text { Average tariffs: } \ln \tau_{c 0}\end{array}$ & -0.002 & (1.36) & 0.001 & $(0.38)$ \\
\hline $\begin{array}{l}\text { Country characteristics } \\
\text { Initial income: } \ln y_{c 0} \\
\text { Initial investment: } \ln i n v_{c 0} \\
\text { Initial human capital: } \ln h k_{c 0}\end{array}$ & $\begin{array}{r}-0.009 \\
0.011 \\
0.011\end{array}$ & $\begin{array}{l}(1.81) \\
(2.46) \\
(3.78)\end{array}$ & $\begin{array}{r}-0.001 \\
0.001 \\
0.002\end{array}$ & $\begin{array}{l}(0.24) \\
(0.18) \\
(0.64)\end{array}$ \\
\hline $\begin{array}{l}\text { Region fixed effects } \\
\text { West Africa } \\
\text { East Africa } \\
\text { South Central Africa } \\
\text { North Africa, Middle East } \\
\text { Eastern Europe } \\
\text { Latin America } \\
\text { East Asia } \\
\text { South East Asia } \\
\text { South West Asia }\end{array}$ & & & $\begin{array}{r}-0.064 \\
-0.048 \\
-0.053 \\
-0.042 \\
-0.021 \\
-0.036 \\
0.001 \\
-0.016 \\
-0.030\end{array}$ & $\begin{array}{l}(3.04) \\
(2.35) \\
(2.48) \\
(2.14) \\
(1.01) \\
(1.91) \\
(0.09) \\
(0.84) \\
(1.53)\end{array}$ \\
\hline $\begin{array}{l}\text { Cohort fixed effects } \\
\quad 1980-1983 \\
1985-1987\end{array}$ & $\begin{array}{r}0.009 \\
-0.002\end{array}$ & $\begin{array}{l}(1.28) \\
(0.30)\end{array}$ & $\begin{array}{l}0.036 \\
0.024\end{array}$ & $\begin{array}{l}(1.98) \\
(1.33)\end{array}$ \\
\hline $\begin{array}{l}R^{2} \\
\text { Observations }\end{array}$ & & & & \\
\hline
\end{tabular}

Notes: The dependent variable is the average annual $\log$ change in per capita GDP in country $c$, $\ln y_{c 1} / y_{c 0}$. There are 63 observations, one for each country.

In column 2 of the table we introduce region fixed effects. ${ }^{4}$ We are using far more regional dummies than is typical. This is an important point. It means the sample variation that we are explaining is all within narrowly defined regions. Thus, for example, once the region fixed effects are included, the three country characteristics become statistically insignificant. This is not surprising: with 63 countries and 10 regions, there is an average of 6.3 observations per region. Note also that since countries within a region have similar geographies, endowments, and histories, we are also implicitly controlling for such factors. Our main point here is that it will be very hard to find a statistically significant country characteristic when so many region fixed effects are included. This, we believe, makes our results for the skill bias of tariffs (a country characteristic) more compelling.

\section{Measures of the Skill Bias of a Country's Tariff Structure}

As Grossman and Helpman (1991) emphasize, their model generalizes to a wide range of settings including both product innovation (horizontal differentiation) and process innovation (vertical differentiation). Further, R\&D need not be interpreted as formal scientific research conducted in labs. In the model it can occur hand-inhand with production, a notion which goes well with Nathan Rosenberg's (1982)

\footnotetext{
${ }^{4}$ See Table 1 for a list of which countries are in which regions.
} 
Table 3-Skill Intensity: Choosing Cut-Offs for Skilled and Unskilled Categories.

\begin{tabular}{|c|c|c|c|}
\hline $\begin{array}{l}\text { Industry } \\
\text { Code }\end{array}$ & Description & $\begin{array}{c}\text { Skill } \\
\text { Intensity }\end{array}$ & $\begin{array}{c}\% \Delta \\
\text { in Skill }\end{array}$ \\
\hline 241 & Leather \& travel goods & 0.079 & $47 \%$ \\
\hline 110 & Agricultural products & 0.116 & $10 \%$ \\
\hline 243 & Wood products & 0.128 & $3 \%$ \\
\hline 245 & Textiles \& clothing & 0.132 & $17 \%$ \\
\hline 247 & Furniture & 0.154 & $19 \%$ \\
\hline 150 & Non-ferrous metals & 0.184 & $9 \%$ \\
\hline $\begin{array}{l}246 \\
--\end{array}$ & $\begin{array}{l}\text { Non-metallic mineral prod. } \\
\text {------- Low Cut-Off ---_--- }\end{array}$ & $\begin{array}{c}0.201 \\
--\end{array}$ & $32 \%$ \\
\hline 220 & Iron \& steel & 0.266 & $18 \%$ \\
\hline 248 & Footwear & 0.315 & $26 \%$ \\
\hline 244 & Paper products & 0.397 & $4 \%$ \\
\hline 231 & Non-electric machinery & 0.414 & $12 \%$ \\
\hline 242 & Rubber products & 0.462 & $0.8 \%$ \\
\hline $\begin{array}{l}233 \\
--\end{array}$ & $\begin{array}{l}\text { Transport equipment } \\
\text {------ High Cut-Off --_-_-- }\end{array}$ & $\begin{array}{c}0.466 \\
--\end{array}$ & $32 \%$ \\
\hline 140 & Mineral fuels & 0.593 & $4 \%$ \\
\hline 232 & Electric machinery & 0.617 & $16 \%$ \\
\hline 211 & Medicaments, toiletry \& perf. & 0.718 & $2 \%$ \\
\hline 213 & Manufactured fertilizers & 0.731 & $9 \%$ \\
\hline 249 & Professional equipment & 0.797 & \\
\hline
\end{tabular}

Notes: Data are from Antweiler and Trefler (2002). Skill intensity is scaled so that the most skill-intensive industry in the Antweiler-Trefler database (electricity generation) has a skill intensity of unity.

incremental innovation done by skilled production workers. Given this, and the fact that there is literally no formal R\&D conducted by many of the countries in our sample, we focus on skill-intensity. ${ }^{5}$

Define industry $i$ 's skill intensity $S_{i} / L_{i}$ as the ratio of the industry's skilled workers (those with 12 years of schooling or more) to unskilled workers (those with less than 12 years of schooling). Table 3 displays $S_{i} / L_{i}$ for the United States in 1972 . We choose 1972 because it is the first year of our sample. The data are from Werner Antweiler and Daniel Trefler (2002) and were calculated from the Current Population Survey. ${ }^{6}$

\footnotetext{
${ }^{5}$ We have presented a very specific model in which there are externalities associated with R\&D. There are also models which focus on human capital externalities (e.g., Robert E. Lucas, Jr. 1988) and in these models skill intensity rather than R\&D intensity would be focal.

${ }^{6}$ The industry codes are UNCTAD industries codes. Appendix B reports the concordance between the UNCTAD industry classification and the ISIC 3-digit classification.
} 
We are using US skill intensities. Yet what is skill intensive in a developed country need not be skill intensive in a developing country. Nevertheless, we obtain virtually identical results using skill-intensity data from South Africa and Brazil. These results are reported in Appendix A.7

Let $c$ index countries and let a 0 subscript denote the first year for which tariff data are available. Our first measure of the skill bias of a country's tariff structure is the cross-industry correlation between initial tariffs $\tau_{i c 0}$ and skill intensity:

\section{Structures." \\ $\rho_{c}=\operatorname{Corr}\left\{\tau_{i c 0}, S_{i} / L_{i}\right\} \quad$ "The Correlation Measure of the Skill Bias of Tariff}

Our second measure is constructed as follows. First, as we did in Table 3, rank industries based on their skill intensities $S_{i} / L_{i}$. Then choose an arbitrary "cut-off" industry $i^{*}$ and treat all industries with $S_{i} / L_{i}$ less than $S_{i^{*}} / L_{i^{*}}$ as unskilled-intensive and all remaining industries as skill-intensive. Let $\tau_{c 0}^{\text {Unskill }}$ be the initial-year, outputweighted average tariff of unskilled-intensive industries and let $\tau_{c 0}^{\text {Skill }}$ be the outputweighted average tariff of skill-intensive industries. Our second measure of skill bias is the percentage difference between $\tau_{c 0}^{\text {Skill }}$ and $\tau_{c 0}^{\text {Unskill }}$, calculated by taking the $\log$ difference of the two measures

$D I F F_{c} \equiv \ln \tau_{c 0}^{\text {Skill }}-\ln \tau_{c 0}^{\text {Unskill }}$ "The Difference Measure of the Skill Bias of Tariff Structures."

An important question is whether our results are sensitive to the choice of $i^{*}$. As shown in Appendix A below, it does not matter what we choose for $i^{*}$ provided it is not extremely close to the very top or very bottom of Table 3. For now, we proceed by reporting results for two choices of $i{ }^{*}$. From Table 3, there are two values of $i$ for which the ratio of skilled to unskilled workers increases significantly. We use these two points to define two different $i^{*}$, which we refer to as the "low cut-off" and the "high cut-off." Let $D I F F_{c}^{\text {Low }}$ and $D I F F_{c}^{\text {High }}$ be the corresponding difference measures.

Summarizing, we will be using three measures of the skill bias of tariffs. These are $\rho_{c}, D I F F_{c}^{\text {Low }}$ and $D I F F_{c}^{H i g h}$.

\section{Estimation with Skill Bias}

Estimates of equation (1), which includes $S B \tau_{c 0}$, are reported in Table 4. Column 1 of the table reports the results using $\rho_{c}$ as our measure of the skill bias of tariff structures. Recall that with so many controls we have not yet found a single countrylevel variable that is statistically significant. In contrast, the coefficient for $\rho_{c}$ has a $t$-statistic of 3.50. The magnitude of the coefficient is very large, a fact that we will detail at the end of this section. Further, the contribution to the $R^{2}$ is very large.

\footnotetext{
${ }^{7}$ The explanation for this surprising robustness is simple. While skill intensities vary across time and countries, the relative ranking of industries based on skill intensities barely varies: leather goods are unskilledintensive everywhere and professional equipment is skill intensive everywhere. The spearman rank correlation coefficients between the US-based skill intensity, and the Brazilian and South African skill intensities are 0.72 and 0.63 , respectively.
} 
Table 4-Country-Level Per Capita GDP Growth Regressions. Dependent Variable is ln yc1/yc0.

\begin{tabular}{|c|c|c|c|c|c|}
\hline & \multirow{2}{*}{$\begin{array}{c}\text { Corr. } \\
(1)\end{array}$} & \multicolumn{2}{|c|}{ Low cut-off } & \multicolumn{2}{|c|}{ High cut-off } \\
\hline & & (2) & (3) & (4) & (5) \\
\hline \multicolumn{6}{|l|}{ Skill bias of tariff structure } \\
\hline Skill tariff correlation: $\rho_{c}$ & $\begin{array}{r}0.035 \\
(3.50)\end{array}$ & & & & \\
\hline Tariff differential: $D I F F_{c}$ & & $\begin{array}{c}0.016 \\
(3.29)\end{array}$ & & $\begin{array}{c}0.020 \\
(4.91)\end{array}$ & \\
\hline Skilled tariff: $\ln \tau^{\text {Skill }}$ & & & $\begin{array}{c}0.018 \\
(3.51)\end{array}$ & & $\begin{array}{r}0.020 \\
(4.94)\end{array}$ \\
\hline Unskilled tariff: $\ln \tau^{\text {Unskill }}$ & & & $\begin{array}{r}-0.015 \\
(3.12)\end{array}$ & & $\begin{array}{c}-0.016 \\
(4.17)\end{array}$ \\
\hline \multicolumn{6}{|l|}{ Other tariff structure } \\
\hline Average tariffs: $\ln \bar{\tau}_{c 0}$ & $\begin{array}{l}0.002 \\
(1.32)\end{array}$ & $\begin{array}{c}0.003 \\
(1.80)\end{array}$ & & $\begin{array}{c}0.005 \\
(2.93)\end{array}$ & \\
\hline \multicolumn{6}{|l|}{ Initial production structure } \\
\hline Skilled-sector output: $\ln q^{\text {Skill }}$ & $\begin{array}{c}0.004 \\
(1.64)\end{array}$ & $\begin{array}{c}0.002 \\
(1.08)\end{array}$ & $\begin{array}{c}0.002 \\
(1.12)\end{array}$ & $\begin{array}{c}0.006 \\
(2.69)\end{array}$ & $\begin{array}{c}0.006 \\
(2.64)\end{array}$ \\
\hline Unskilled-sector output: $\ln q^{\text {Unskill }}$ & $\begin{array}{c}-0.006 \\
(1.87)\end{array}$ & $\begin{array}{c}-0.004 \\
(1.30)\end{array}$ & $\begin{array}{c}-0.004 \\
(1.38)\end{array}$ & $\begin{array}{c}-0.010 \\
(3.39)\end{array}$ & $\begin{array}{c}-0.010 \\
(3.34)\end{array}$ \\
\hline 3 country characteristics & Yes & Yes & Yes & Yes & Yes \\
\hline 9 region fixed effects & Yes & Yes & Yes & Yes & Yes \\
\hline 2 cohort fixed effects & Yes & Yes & Yes & Yes & Yes \\
\hline$R^{2}$ & 0.71 & 0.70 & 0.70 & 0.77 & 0.76 \\
\hline
\end{tabular}

Notes: The dependent variable is the average annual growth of per capita GDP in country $c, \ln y_{c 1} / y_{c 0}$. There are 63 observations, one for each country. $\ln q_{c 0}^{\text {Skill }}$ is $\log$ output of all skill-intensive industries. $\ln q_{c 0}^{\text {Unskill }}$ is $\log$ output of all unskilled-intensive industries. The "3 country characteristics" are initial-year per capita GDP, initialyear investment-to-GDP ratio, and initial-year human capital stock. See Table 2 for a description of the region and cohort fixed effects.

Adding just $\rho_{c}$ to the regression raises the $R^{2}$ from 0.60 to 0.71 .8 The fact that a single regressor could have such a large effect in a specification that already has 18 regressors is striking.

Column 2 replaces $\rho_{c}$ with $D I F F_{c}^{\text {Low }}$ as our measure of the skill bias of the tariff structure. The results are again statistically significant $(t=3.29)$. DIFF $F_{c}^{\text {Low }}$ raises the $R^{2}$ from 0.60 to 0.70 . Column 4 uses $D I F F_{c}^{\text {High }}$ as our measure. The results are similar to those for $D I F F_{c}^{\text {Low }}$.

To better understand what is driving the $D I F F_{c} \equiv \ln \tau_{c 0}^{\text {Skill }}-\ln \tau_{c 0}^{\text {Unskill }}$ results, we introduce $\ln \tau_{c 0}^{\text {Skill }}$ and $\ln \tau_{c 0}^{\text {Unskill }}$ separately. In column 3 we do this for the low cut-off. The coefficient for $\ln \tau_{c 0}^{\text {Skill }}$ is positive and significant $(t=3.51)$, and the coefficient for $\ln \tau_{c 0}^{\text {Unskill }}$ is negative and significant $(t=3.12)$. These results show that it is not only a positive effect from $\ln \tau_{c 0}^{\text {Skill }}$ or a negative effect from $\ln \tau_{c 0}^{\text {Unskill }}$ that dominates in determining the significance of $D I F F_{c}$. Rather, it is both variables, and hence the difference between the two, that is important.

\footnotetext{
${ }^{8}$ Note that when including $\rho_{c}$ we also control for initial industrial structure. (We will describe these controls in detail below.) Adding the controls for industrial structure in the regression of column 1, Table 2 raises the $R^{2}$ slightly from 0.60 to 0.61 . Adding $\rho_{c}$ further raises the coefficient from 0.61 to 0.71 (column 1 , Table 4).
} 
The estimated magnitudes of the relationship between the skill bias of tariffs and long-term growth are large. A one standard deviation increase in $\rho_{c}$ raises per capita GDP growth by 0.88 percent. For $D I F F_{c}^{\text {Low }}$ and $D I F F_{c}^{\text {High }}$ the increases are 0.88 percent and 1.20 percent, respectively. ${ }^{9}$

Guided by the model, we also include two other regressors that control for the initial production structure of the economy. Recall from Table 3 that $i^{*}$ is the boundary industry between skill- and unskilled-intensive industries. Let $q_{c 0}^{\text {Skill }} \equiv \Sigma_{i>i}{ }^{*} q_{i c 0}$ and $q_{c 0}^{\text {Unskill }} \equiv \Sigma_{i \leq i} * q_{i c 0}$ be the natural logs of output of the skill- and unskilled-intensive industries in the initial period. ${ }^{10}$ Across all specification skilled-sector output enters with a positive coefficient and unskilled-sector output with a negative coefficient. This is consistent with the predictions of the model where comparative advantage and aggregate GDP growth are also determined by the share of initial-period production in the skilled (i.e., R\&D intensive) sectors.

To check that the results are not being driven by outliers, Figures $1 \mathrm{a}$ and $1 \mathrm{~b}$ display partial regression plots. Figure 1a shows the partial regression plot for $\rho_{c}$ from column 1. Figure $1 \mathrm{~b}$ shows the partial regression plot for $D I F F_{c}^{\text {Low }}$ from column 2. From the plots it is clear that our results are not driven by a small number of influential observations. In Appendix A, we show that the results are robust to systematically omitting influential observations.

Appendix A also shows that the results are not driven by sample variation between rich and poor countries. When the 10 richest countries in the sample are omitted our results are actually strengthened. Thus, within-region sample variation among poor countries is important for our results. ${ }^{11}$

\section{Real Effects of Tariffs}

\section{A. Industry-Level Mechanisms}

In the model outlined in Section I, protection of the R\&D-intensive industry can lead to an expansion of varieties, which in turn creates a positive externality and increases per capita GDP growth. More generally, a skill-biased tariff structure may have a path-dependent impact on growth by shifting resources into externality-generating, skill-intensive industries. This implies that at the industry level there should be a positive correlation between initial tariffs and subsequent output growth. Tariffs should expand output of the industry they are protecting. We refer to this as the ownindustry effect.

To test whether this effect is present in the data we move to the sub-national level and examine output growth at the industry level. Let $q_{i c t}$ be the output of industry

\footnotetext{
${ }^{9}$ See Table 13 for the summary statistics used to calculate these effects.

${ }^{10}$ Depending on whether we use $D I F F_{c}^{\text {Low }}$ or $D I F F_{c}^{\text {High }}$ we use different cut-offs $i^{*}$ to define $q_{c t}^{\text {Skill }}$ and $q_{c t}^{\text {Unskill }}$. In specifications that use $\rho_{c}$ we define $q_{c t}^{\text {Skill }}$ and $q_{c t}^{\text {Unskill }}{ }^{c}$ using the low cut-off. Results are identical if we use the high cut-off instead.

${ }^{11}$ Note that the average tariff is now significant. Oddly, it is positive rather than the expected negative. It does not matter for our skill bias results whether we control for the average tariff or not.
} 
Panel A. Average annual per capita GDP growth and $\rho_{c}$.

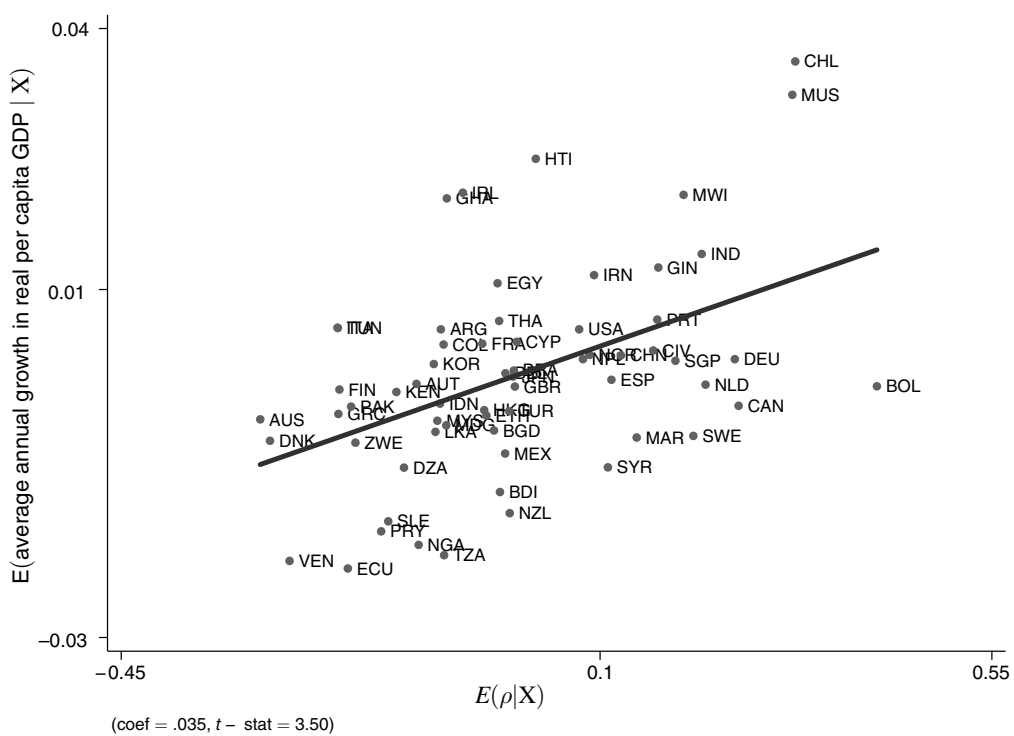

Panel B. Average annual per capita GDP growth and DIFF Low

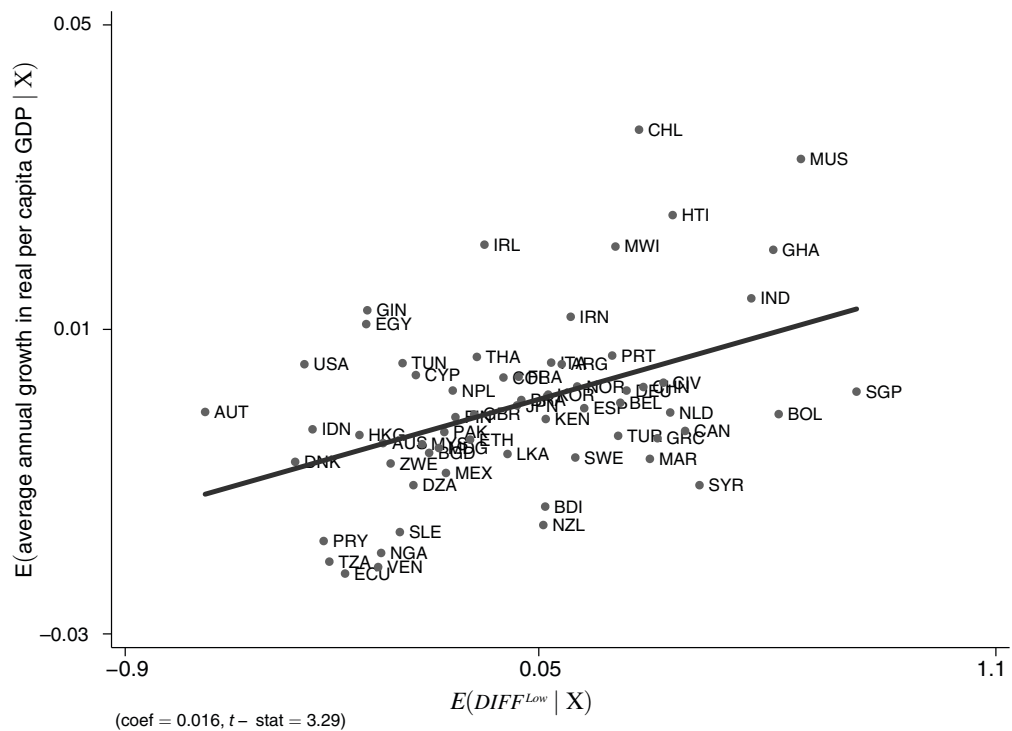

Figure 1. Partial Regression Plots

$i$ in country $c$ in year $t$. Our dependent variable is the average annual log change in industry output, $\ln q_{i c 1} / q_{i c 0} \cdot{ }^{12}$ The sources of the production data are discussed in Appendix B.

\footnotetext{
${ }^{12}$ As in the discussion preceding equation (1) above, more precise notation would be $\left(1 /\left(t_{c 1}-t_{c 0}\right)\right) \ln q_{i, c, t_{c 1}} / q_{i, c, t_{c 0}}$.
} 
Table 5-Industry-Country Level Output Growth Regressions. Dependent Variable is $\ln q_{i c 1} / q_{i c 0}$.

\begin{tabular}{|c|c|c|c|c|c|}
\hline & \multirow{2}{*}{$\begin{array}{c}\text { Correlation } \\
(1)\end{array}$} & \multicolumn{2}{|c|}{ Low cut-off } & \multicolumn{2}{|c|}{ High cut-off } \\
\hline & & (2) & (3) & (4) & (5) \\
\hline \multicolumn{6}{|l|}{ Skill bias of tariff structure } \\
\hline Skill tariff correlation: $\rho_{c}$ & $\begin{array}{r}0.064 \\
(3.18)\end{array}$ & & & & \\
\hline Tariff differential: $D I F F_{c}$ & & $\begin{array}{c}0.032 \\
(3.18)\end{array}$ & & $\begin{array}{c}0.040 \\
(4.45)\end{array}$ & \\
\hline Skilled tariff: $\ln \tau^{\text {Skill }}$ & & & $\begin{array}{r}0.040 \\
(4.02)\end{array}$ & & $\begin{array}{r}0.043 \\
(4.69)\end{array}$ \\
\hline Unskilled tariff: $\ln \tau^{\text {Unskill }}$ & & & $\begin{array}{r}-0.027 \\
(2.64)\end{array}$ & & $\begin{array}{r}-0.026 \\
(2.87)\end{array}$ \\
\hline Initial industry output: $\ln q_{i c 0}$ & Yes & Yes & Yes & Yes & Yes \\
\hline Average tariffs: $\ln \tau_{c 0}$ & Yes & Yes & Yes & Yes & Yes \\
\hline Initial production structure & Yes & Yes & Yes & Yes & Yes \\
\hline 3 country characteristics & Yes & Yes & Yes & Yes & Yes \\
\hline All fixed effects & Yes & Yes & Yes & Yes & Yes \\
\hline$R^{2}$ & 0.35 & 0.35 & 0.35 & 0.36 & 0.36 \\
\hline
\end{tabular}

Notes: The dependent variable is the average annual log change of output in industry $i$ in country $c, \ln q_{i c 1} / q_{i c 0}$. There are 18 industries, 59 countries, and 1,004 observations. $t$-statistics are calculated from standard errors adjusted for clustering at the country level. "Initial production structure" variables are $\ln q_{c 0}^{\text {Skill }}$ and $\ln q_{c 0}^{\text {Unskill }}$. In col-

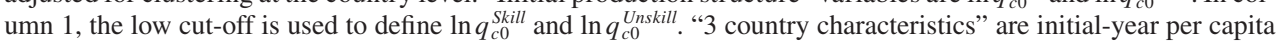
GDP, initial-year investment-to-GDP ratio, and initial-year human capital stock. "All fixed effects' are the 9 region fixed effects and 2 cohort fixed effects listed in Table 2, as well as 16 industry fixed effects.

Our panel estimating equation is

$$
\begin{aligned}
\ln q_{i c 1} / q_{i c 0}= & \beta_{q} \ln q_{i c 0}+\beta_{\tau} \ln \tau_{i c 0}+\beta_{E} \ln \bar{\tau}_{c 0}+\beta_{S B} S B \tau_{c 0} \\
& +\mathbf{X}_{c 0} \beta_{X}+\alpha_{i}+\varepsilon_{i c}
\end{aligned}
$$

where $\ln q_{i c 0}$ is the $\log$ of output in industry $i$ and country $c$ in the initial period, $\ln \tau_{i c 0}$ is the $\log$ initial-period tariff, and as before $\bar{\tau}_{c 0}$ denotes the average tariff and $S B \tau_{c 0}$ denotes the skill bias of tariffs. $\mathbf{X}_{c 0}$ collects all the regressors that we used in the cross-country regressions. We also include industry fixed effects $\alpha_{i}$ to control for country-invariant industry characteristics.

We are interested in how $\beta_{S B}$ changes when we add in $\ln \tau_{i c 0} . \beta_{\tau}$ is the impact of country $c$ 's tariff in industry $i$ on output growth in the same industry. This is the ownindustry effect. If it explains our correlation of growth with the skill bias of tariffs, then after controlling for tariffs at the industry level $\beta_{S B}$ should become much smaller.

Due to missing production data, the industry-level sample consists of 59 countries, which is four countries less than the country-level regressions. ${ }^{13}$ As a result, there are potentially 1,062 (= $59 \times 18)$ industry-level observations. However, because some of the output data are missing, we work with 1,004 industry-country level observations.

Tables 5 and 6 report estimates of equation (2). Table 5 reports estimates of equation (2) with $\ln \tau_{i c 0}$ excluded and Table 6 reports estimates with $\ln \tau_{i c 0}$. In Table 5,

\footnotetext{
${ }^{13}$ The four countries are Guinea, Haiti, Madagascar, and Paraguay.
} 
Table 6-Industry-Country Level Output Growth Regressions, Controlling for Own-Industry Channels. Dependent Variable is $\ln q_{i c 1} / q_{i c 0}$.

\begin{tabular}{|c|c|c|c|c|c|c|c|c|c|c|}
\hline & \multicolumn{2}{|c|}{ Correlation } & \multicolumn{4}{|c|}{ Low cut-off } & \multicolumn{4}{|c|}{ High cut-off } \\
\hline & (1) & (2) & (3) & (4) & (5) & (6) & (7) & (8) & (9) & (10) \\
\hline $\begin{array}{l}\text { Skill bias of tariff structure } \\
\text { Skill tariff correlation: } \rho_{c}\end{array}$ & $\begin{array}{c}0.066 \\
(3.40)\end{array}$ & $\begin{array}{r}0.069 \\
(3.56)\end{array}$ & & & & & & & & \\
\hline Tariff differential: $D I F F_{c}$ & & & $\begin{array}{r}0.033 \\
(3.43)\end{array}$ & $\begin{array}{r}0.035 \\
(3.61)\end{array}$ & & & $\begin{array}{r}0.039 \\
(4.43)\end{array}$ & $\begin{array}{r}0.039 \\
(4.49)\end{array}$ & & \\
\hline Skilled tariff: $\ln \tau^{\text {Skill }}$ & & & & & $\begin{array}{c}0.038 \\
(3.94)\end{array}$ & $\begin{array}{c}0.038 \\
(4.00)\end{array}$ & & & $\begin{array}{c}0.040 \\
(4.57)\end{array}$ & $\begin{array}{r}0.041 \\
(4.60)\end{array}$ \\
\hline Unskilled tariff: $\ln \tau^{\text {Unskill }}$ & & & & & $\begin{array}{r}-0.030 \\
(3.02)\end{array}$ & $\begin{array}{r}-0.032 \\
(3.27)\end{array}$ & & & $\begin{array}{r}-0.029 \\
(3.24)\end{array}$ & $\begin{array}{r}-0.031 \\
(3.45)\end{array}$ \\
\hline \multicolumn{11}{|l|}{ Own-industry channels } \\
\hline $\begin{array}{l}\text { Initial industry tariff: } \\
\quad \ln \tau_{i c 0}\end{array}$ & $\begin{array}{c}0.006 \\
(2.84)\end{array}$ & $\begin{array}{r}0.014 \\
(4.98)\end{array}$ & $\begin{array}{r}0.006 \\
(2.84)\end{array}$ & $\begin{array}{r}0.014 \\
(4.52)\end{array}$ & $\begin{array}{l}0.006 \\
(2.68)\end{array}$ & $\begin{array}{r}0.014 \\
(4.47)\end{array}$ & $\begin{array}{r}0.005 \\
(2.45)\end{array}$ & $\begin{array}{r}0.013 \\
(4.32)\end{array}$ & $\begin{array}{r}0.005 \\
(2.49)\end{array}$ & $\begin{array}{r}0.013 \\
(4.45)\end{array}$ \\
\hline $\begin{array}{l}\text { Tariff-skill interaction: } \\
\quad \ln \tau_{i c 0} \times S_{i} / L_{i}\end{array}$ & & $\begin{array}{r}-0.015 \\
(2.87)\end{array}$ & & $\begin{array}{r}-0.015 \\
(2.77)\end{array}$ & & $\begin{array}{c}-0.014 \\
(2.75)\end{array}$ & & $\begin{array}{r}-0.014 \\
(2.62)\end{array}$ & & $\begin{array}{r}-0.014 \\
(2.68)\end{array}$ \\
\hline Initial industry output: $\ln q_{i c 0}$ & Yes & Yes & Yes & Yes & Yes & Yes & Yes & Yes & Yes & Yes \\
\hline Average tariffs: $\ln \tau_{c 0}$ & Yes & Yes & Yes & Yes & Yes & Yes & Yes & Yes & Yes & Yes \\
\hline Initial production structure & Yes & Yes & Yes & Yes & Yes & Yes & Yes & Yes & Yes & Yes \\
\hline 3 country characteristics & Yes & Yes & Yes & Yes & Yes & Yes & Yes & Yes & Yes & Yes \\
\hline All fixed effects & Yes & Yes & Yes & Yes & Yes & Yes & Yes & Yes & Yes & Yes \\
\hline$R^{2}$ & 0.35 & 0.36 & 0.36 & 0.36 & 0.36 & 0.36 & 0.37 & 0.38 & 0.37 & 0.38 \\
\hline
\end{tabular}

Notes: The dependent variable is the average annual log change of output in industry $i$ in country $c, \ln q_{i c 1} / q_{i c 0}$. There are 18 industries, 59 countries and 1,004 observations. $t$-statistics are calculated from standard errors adjusted for clustering at the country level. "Initial production structure" variables are $\ln q_{c 0}^{\text {skill }}$ and $\ln q_{c 0}^{\text {Unskill }}$. In columns 1-2, the low cut-off is used to define $\ln q_{c 0}^{\text {skill }}$ and $\ln q_{c 0}^{\text {Unskill. }}$ " 3 country characteristics" are initial-year per capita GDP, initial-year investment-to-GDP ratio, and initial-year human capital stock. "All fixed effects" are the 9 region fixed effects and 2 cohort fixed effects listed in Table 2 as well as 16 industry fixed effects.

each column reports results for a different measure of $S B \tau_{c 0}$. In all columns, the estimated coefficients for the various skill-bias-of-tariff variables have the expected signs and are statistically significant $(t$-statistics are calculated from standard errors clustered at the country level). Thus, the skill-bias-of-tariff measures are positively correlated with output growth in all industries. Further, the coefficient magnitudes are large. Consider column 1 of Table 5 where the coefficient on $\rho_{c}$ is 0.064 . A one standard deviation increase in $\rho_{c}$ leads to a 1.60 percent increase in average annual industry output growth. ${ }^{14}$ For $D I F F_{c}^{\text {Low }}$ of column 2 and $D I F F_{c}^{\text {High }}$ of column 4 the increase in average annual industry output growth is 1.76 percent and 2.32 percent, respectively. These are very large effects.

In Table 6, we add $\ln \tau_{i c 0}$ to the regressions (see columns 1, 3, 5, 7, and 9). The estimated coefficients for $\ln \tau_{i c 0}$ are positive and statistically significant in all specifications. This means that a tariff in industry $i$ is positively associated with subsequent output growth in that industry. These own-industry effects are large. A one standard deviation increase in $\ln \tau_{i c 0}$ raises the average annual growth of industry $i$ output by 
between 1.01 percent and 1.21 percent, depending on the specification. ${ }^{15}$ However, despite the fact that these effects are large, the coefficients on the skill-bias-of-tariff variables remain virtually unchanged when own-industry tariffs are included in the regressions. This suggests that the impact of industry tariffs on industry output growth is almost completely orthogonal to the effect of skill-biased tariffs on output growth.

In the remaining columns of Table 6 (columns 2, 4, 6, 8, and 10) we step outside of the model and test for an alternative explanation for the importance of skill-biased tariffs. If skill-intensive industries have a greater scope for learning-by-doing externalities that are strictly firm- or industry-specific in scope, then the own-industry effect should be higher in skill-intensive industries. To examine this learning-bydoing channel we interact $\ln \tau_{i c 0}$ with $S_{i} / L_{i}$ and check if the coefficient on $\ln \tau_{i c 0} \cdot S_{i} / L_{i}$ is positive. In fact, it is significantly negative. This means that the learning-by-doing channel is completely absent.

More importantly for our interests, the inclusion of both $\ln \tau_{i c 0}$ and $\ln \tau_{i c 0} \cdot S_{i} / L_{i}$ into the regressions does not alter the coefficients on our skill-bias-of-tariff variables. This provides further evidence that our estimated correlation of growth with the skill bias of tariffs cannot be explained by own-industry effects.

The important takeaway from our industry-country level analysis is that although we do find evidence of real effects of tariffs (i.e., own industry effects), they are unable to account for the correlation between the skill bias of tariffs and output growth.

\section{B. General Equilibrium Mechanisms}

We now return to the country level to examine additional evidence for the mechanism from our model. By working at the country level, we are also able to test for other general equilibrium benefits of a skill-biased tariff structure that are not captured by our model.

The analysis requires a measure of the growth of skill-intensive industries relative to unskilled industries. Recall from Table 3 that $i^{*}$ is the boundary industry between skill- and unskilled-intensive industries. As before, let $q_{c t}^{\text {Skill }} \equiv \Sigma_{i>i} q_{i c t}$ and $q_{c t}^{\text {Unskill }} \equiv \Sigma_{\mathrm{i} \leq i^{*}} q_{i c t}$ be the output of the skill- and unskilled-intensive industries in the initial period $(t=0)$ and final period $(t=1)$. Our measure is the average annual change in $q_{c}^{\text {Skill }} / q_{c}^{\text {Unskill }}$ between the two periods, $\left(1 /\left(t_{c 1}-t_{c 0}\right)\right)$ $\left(\ln q_{c 1}^{\text {Skill }} / q_{c 1}^{\text {Unskill }}-\ln q_{c 0}^{\text {Skill }} / q_{c 0}^{\text {Unskill }}\right)$, which we denote by $\Delta \ln q_{c}^{\text {Skill }} / q_{c}^{\text {Unskill } .16}$

As a test of whether the model's mechanism is able to explain the relationship between the skill bias of tariffs and growth, we examine whether: countries with a more skill-biased tariff structure experience disproportionately faster output growth in skill-intensive industries; countries that experience this faster output growth also experience faster aggregate per capita GDP growth; and the faster output expansion

\footnotetext{
${ }^{15}$ If one is only interested in estimating the coefficient for $\ln \tau_{i c 0}$, and not the coefficient for the skill-bias-oftariff variables, then all country-specific variables can be replaced with country fixed effects in equation (2). This specification yields an estimate of the own-industry effect that is similar to the estimates we report here (coef $=$ $0.004, t$-stat $=2.07$.

${ }^{16}$ A natural alternative to $\Delta \ln q_{c}^{\text {Skill }} / q_{c}^{\text {Unskill }}$ is the change in the average skill intensity of production over the two periods. The results using this variable are essentially identical to what we report with $\Delta \ln q_{c}^{\text {Skill }} / q_{c}^{\text {Unskill }}$.
} 
Table 7-Controlling For Changes in Industrial Structure.

\begin{tabular}{|c|c|c|c|c|c|c|c|c|}
\hline & \multicolumn{3}{|c|}{$\Delta \ln q^{\text {Skill }} / q^{\text {Unskill }}$} & \multicolumn{5}{|c|}{$\ln y_{c 1} / y_{c 0}$} \\
\hline & $\begin{array}{l}\text { Corr. } \\
\text { (1) }\end{array}$ & $\begin{array}{l}\text { Low } \\
(2)\end{array}$ & $\begin{array}{l}\text { High } \\
\text { (3) }\end{array}$ & $\begin{array}{l}\text { Low } \\
(4)\end{array}$ & $\begin{array}{l}\text { High } \\
(5)\end{array}$ & $\begin{array}{l}\text { Corr. } \\
(6)\end{array}$ & $\begin{array}{l}\text { Low } \\
(7)\end{array}$ & $\begin{array}{l}\text { High } \\
(8)\end{array}$ \\
\hline \multicolumn{9}{|l|}{ Skill bias of tariff structure } \\
\hline Skill tariff correlation: $\rho_{c}$ & $\begin{array}{l}0.096 \\
(2.65)\end{array}$ & & & & & $\begin{array}{l}0.026 \\
(2.46)\end{array}$ & & \\
\hline Tariff differential: $D I F F_{c}$ & & $\begin{array}{r}0.042 \\
(2.31)\end{array}$ & $\begin{array}{c}0.035 \\
(1.93)\end{array}$ & & & & $\begin{array}{r}0.012 \\
(2.34)\end{array}$ & $\begin{array}{r}0.017 \\
(3.90)\end{array}$ \\
\hline $\begin{array}{l}\text { General equilibrium channe } \\
\qquad \Delta \ln q^{\text {Skill }} / q^{\text {Unskill }}\end{array}$ & & & & $\begin{array}{c}0.103 \\
(2.50)\end{array}$ & $\begin{array}{c}0.084 \\
(2.26)\end{array}$ & $\begin{array}{c}0.061 \\
(1.43)\end{array}$ & $\begin{array}{c}0.066 \\
(1.56)\end{array}$ & $\begin{array}{c}0.038 \\
(1.13)\end{array}$ \\
\hline Average tariffs: $\ln \bar{\tau}_{c 0}$ & Yes & Yes & Yes & Yes & Yes & Yes & Yes & Yes \\
\hline Initial production structure & Yes & Yes & Yes & Yes & Yes & Yes & Yes & Yes \\
\hline 3 country characteristics & Yes & Yes & Yes & Yes & Yes & Yes & Yes & Yes \\
\hline All fixed effects & Yes & Yes & Yes & Yes & Yes & Yes & Yes & Yes \\
\hline$R^{2}$ & 0.59 & 0.57 & 0.45 & 0.70 & 0.70 & 0.74 & 0.74 & 0.78 \\
\hline
\end{tabular}

Notes: In columns $1-3$, the dependent variable is $\Delta \ln q^{\text {Skill }} / q^{\text {Unskill }}$; in columns $4-8$ it is $\ln y_{c 1} / y_{c 0}$. In each regression, the number of observations is 59. "Initial production structure" variables are $\ln q_{c 0}^{\text {Skill }}$ and $\ln q_{c 0}^{\text {Unskill }}$. 3 country characteristics" are initial-year per capita GDP, initial-year investment-to-GDP ratio, and initial-year human capital stock. "All fixed effects" are the 9 region fixed effects and 2 cohort fixed effects listed in Table 4.

is able to fully account for the relationship between the skill bias of tariffs and per capita GDP growth.

Estimates are reported in Table 7. The first three columns estimate the relationship between the skill bias of tariffs and $\Delta \ln q_{c}^{\text {Skill }} / q_{c}^{\text {Unskill }}$. We estimate our country-level equation (1), but with $\Delta \ln q_{c}^{\text {Skill }} / q_{c}^{\text {Unskill }}$ as the dependent variable. Each of the three columns reports estimates for a different measure of skill-biased tariffs. Columns 4-5 regress growth in real per capita GDP on $\Delta \ln q_{c}^{\text {Skill }} / q_{c}^{\text {Unskill }}$ (defined by the low and high cut-off), controlling for our full set of covariates.

The estimates provide support for the model's mechanism. There is a positive impact of skill-biased tariffs on $\Delta \ln q_{c}^{\text {Skill }} / q_{c}^{\text {Unskill }}$ (columns 1-3), and a positive impact of $\Delta \ln q_{c}^{\text {Skill }} / q_{c}^{\text {Unskill }}$ on real per capita GDP growth (columns 4-5).

The point estimates can be used to calculate an estimated effect of the skill bias of tariffs on growth through the mechanism highlighted in our model. The effect is calculated as the coefficient for the skill bias of tariffs (reported in columns 1-3) multiplied by the relevant coefficient for $\Delta \ln q_{c}^{\text {Skill }} / q_{c}^{\text {Unskill }}$ (from columns 4-5). For $\rho_{c}$ this is $0.096 \times 0.103=0.0099$. Similarly, for DIFF $F_{c}^{\text {Low }}$ it is $0.042 \times 0.103=0.0043$, and for $D I F F_{c}^{\text {High }}$ it is $0.035 \times 0.084=0.0029$. The figures can be compared to the reduced-form relationship between the skill bias of tariffs and growth from Table 4 . Doing this one finds that the mechanism is only able to account for 15-28 percent of the total correlation between the skill bias of tariffs and growth, depending on which measure of skill-biased tariffs is used. ${ }^{17}$

\footnotetext{
${ }^{17}$ These are calculated as $0.0099 \div 0.035,0.0043 \div 0.016$, and $0.0029 \div 0.020$, for $\rho_{c}, D I F F_{c}^{\text {Low }}$, and DIFF $F_{c}^{\text {High }}$ respectively.
} 
An alternative strategy is to re-estimate equation (1), while controlling for $\Delta \ln$ $q_{c}^{\text {Skill }} / q_{c}^{\text {Unskill }}$. One can then observe how much the coefficient on the skill bias of tariffs decreases relative to the baseline. These estimates are reported in columns 6-8 of Table 7. Controlling for $\Delta \ln q_{c}^{\text {Skill }} / q_{c}^{\text {Unskill }}$ reduces the coefficient for the skill bias of tariffs by 25 percent for $\rho_{c}$ and $D I F F_{c}^{\text {Low }}$, and by 15 percent for $D I F F_{c}^{\text {High }}$. These estimates are surprisingly consistent with the 15-28 percent range calculated from the estimates in columns $1-5$. Therefore, although we find evidence for our model's mechanism, it is only able to account for approximately 25 percent of the total correlation.

We recognize that the stylized model we presented highlights only one specific mechanism through which the initial structure of tariffs can impact on growth. Stepping outside of the model, one can easily find other plausible mechanisms that are widely discussed, e.g., Grossman and Helpman (1991, chapters 5 and 9) and Luis A. Rivera-Batiz and Paul M. Romer (1991). We now ask whether these alternative mechanisms can explain the remaining portion of the correlation between the skill bias of tariffs and growth.

Since a skill-biased tariff structure expands the production of skill-intensive industries, this expansion may in turn raise the demand for and hence the returns to human capital. Higher returns may accelerate human capital formation, which can benefit a broad range of industries. Similarly, protection of skill-intensive industries may raise the returns to $R \& D$ and other forms of knowledge creation, which also have benefits for the broader economy. ${ }^{18}$

We consider two new variables to test whether these explanations can account for the relationship between the skill bias of tariffs and long-term growth. The first is the average annual change in the stock of human capital over the period. We use data from Robert J. Barro and Jong-Wha Lee (2001) to calculate the average annual change in $h k_{c}$ from the initial period to 2000 . We denote this by $\Delta \ln h k_{c}$. The second is the average annual change in knowledge creation over the period. We measure knowledge creation in a country by the number of US patents taken out by inventors from that country. The patent data are from Adam B. Jaffe and Manuel Trajtenberg (2002). We calculate the average number of patents taken out by a country in the five years before the initial period. This is our measure of initial knowledge creation. Final knowledge creation is the average annual number of patents taken out by the country between 1998 and 2002. We then calculate the average annual percentage change in new patents from the initial to final period for each country, which we denote by $\Delta \ln$ patent $_{c} \cdot{ }^{19}$

Estimates are reported in Table 8 and 9. Table 8 reports estimates for human capital accumulation $\Delta \ln h k_{c}$ and Table 9 reports estimates for knowledge accumulation

\footnotetext{
${ }^{18}$ Grossman and Helpman (1991, chapter 5) present such a model. Note, though, that skill-biased tariffs have two offsetting effects in this class of models. First, by raising the skill premium it encourages human capital formation. Second, by raising the skill premium, it makes R\&D more expensive, thus reducing any externalities operating through accumulation of stocks of knowledge.

${ }^{19}$ Note that because the variable is a differenced measure, we are differencing out country-specific fixed effects, such a country's propensity to apply for a US patent. Also note that we do not deal with right truncation. Finally, if both the initial and final patent numbers are 0 for country $c$ then we set $\Delta$ patent $_{c}=0$. This is the case for 8 of our countries. For 5 countries, the initial period patents are zero, but the final period number is positive. For these countries, we set the initial period value to 0.1 when calculating the growth rate.
} 
Table 8-Controlling for Human Capital Accumulation.

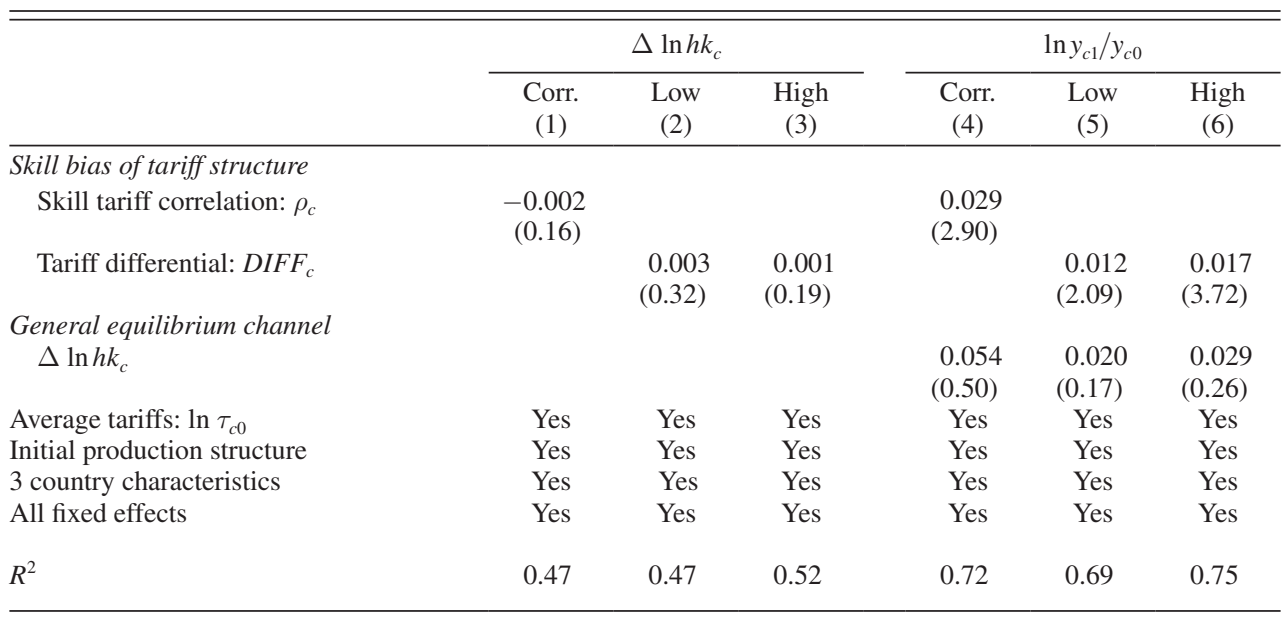

Notes: In columns $1-3$, the dependent variable is $\Delta \ln h k_{c}$; in columns $4-6$, it is $\ln y_{c 1} / y_{c 0}$. In all regressions, the number of observations is 55. "Initial production structure" variables are $\ln q_{c 0}^{\text {Skill }}$ and $\ln q_{c 0}^{\text {Unskill }}$. " 3 country characteristics" are initial-year per capita GDP, initial-year investment-to-GDP ratio, and initial-year human capital stock. "All fixed effects" are the 9 region fixed effects and 2 cohort fixed effects listed in Table 4.

$\Delta \ln$ patent $_{c}$. We find no evidence that a skill-biased tariff structure increases subsequent human capital accumulation (Table 8, columns 1-3), or increases knowledge accumulation (Table 9, columns 1-3). We also find that controlling for either variable has no significant effect on the relationship between the skill bias of tariffs and growth (columns 4-6 of Tables 8 and 9).20

There are many possible reasons why we do not find evidence that a skill-biased tariff structure affects growth through the accumulation of human capital and knowledge creation. One is that although the increased demand for human capital from a skilled-biased tariff structure may increase the accumulation of human capital, which is good for growth, it also drives up the wage rate, making skill-intensive activities (including R\&D) more expensive, thus hurting growth.

\section{The Structure of Tariffs when Protection is for Sale}

To this point in the analysis, we have documented a very strong positive correlation between the skill bias of tariffs and long-term growth. We found evidence for the mechanism highlighted in our model. But we also found that the mechanism can at most account for about a quarter of the total correlation between skill-biased tariffs and growth. We now turn to an alternative explanation that centers on the endogeneity of the tariff structure. ${ }^{21}$

\footnotetext{
${ }^{20}$ The coefficients for the skill bias of tariffs in columns 4-6 of Table 8 are slightly lower than the baseline estimates reported in Table 4. However, this is entirely the result of the smaller sample of 55 countries in the regressions with $\Delta \ln h k_{c}$. Comparing the baseline estimates using the sample of 55 countries with the estimates controlling for $\Delta \ln h k_{c}$, one finds that the coefficients for the skill bias of tariffs are essentially identical.

${ }^{21}$ Surprisingly, the endogeneity of tariffs has by and large remained absent from the tariffs-growth literature. Rodriguez and Rodrik (2001), Douglas A. Irwin (2002), and Rodrik (2005) discuss the issue of endogeneity, but
} 
Table 9-Controlling for Knowledge Creation

\begin{tabular}{|c|c|c|c|c|c|c|}
\hline & \multicolumn{3}{|c|}{$\Delta \ln$ patent $_{c}$} & \multicolumn{3}{|c|}{$\ln y_{c 1} / y_{c 0}$} \\
\hline & $\begin{array}{l}\text { Corr. } \\
\text { (1) }\end{array}$ & $\begin{array}{l}\text { Low } \\
\text { (2) }\end{array}$ & $\begin{array}{l}\text { High } \\
\text { (3) }\end{array}$ & $\begin{array}{c}\text { Corr. } \\
\text { (4) }\end{array}$ & $\begin{array}{l}\text { Low } \\
(5)\end{array}$ & $\begin{array}{c}\text { High } \\
\text { (6) }\end{array}$ \\
\hline \multicolumn{7}{|l|}{ Skill bias of tariff structure } \\
\hline Skill tariff correlation: $\rho_{c}$ & $\begin{array}{c}-0.008 \\
(0.15)\end{array}$ & & & $\begin{array}{c}0.035 \\
(3.55)\end{array}$ & & \\
\hline Tariff differential: $D I F F_{c}$ & & $\begin{array}{r}0.007 \\
(0.28)\end{array}$ & $\begin{array}{c}-0.033 \\
(1.52)\end{array}$ & & $\begin{array}{c}0.017 \\
(3.60)\end{array}$ & $\begin{array}{r}0.019 \\
(4.75)\end{array}$ \\
\hline \multicolumn{7}{|l|}{ General equilibrium channel } \\
\hline$\Delta \ln$ patent $_{c}$ & & & & $\begin{array}{l}-.043 \\
(1.51)\end{array}$ & $\begin{array}{c}-0.056 \\
(1.94)\end{array}$ & $\begin{array}{l}-.035 \\
(1.33)\end{array}$ \\
\hline Average tariffs: $\ln \tau_{c 0}$ & Yes & Yes & Yes & Yes & Yes & Yes \\
\hline Initial production structure & Yes & Yes & Yes & Yes & Yes & Yes \\
\hline 3 country characteristics & Yes & Yes & Yes & Yes & Yes & Yes \\
\hline All fixed effects & Yes & Yes & Yes & Yes & Yes & Yes \\
\hline$R^{2}$ & 0.66 & 0.66 & 0.68 & 0.72 & 0.72 & 0.77 \\
\hline
\end{tabular}

Notes: In columns $1-3$, the dependent variable is $\Delta \ln$ patent $_{c}$; in columns $4-6$, it is $\ln y_{c 1} / y_{c 0}$. In all regressions, the

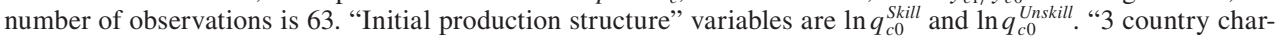
acteristics" are initial-year per capita GDP, initial-year investment-to-GDP ratio, and initial-year human capital stock. "All fixed effects" are the 9 region fixed effects and 2 cohort fixed effects listed in Table 4.

We begin by presenting a model of tariff structure that is an extension of Grossman and Helpman's (1994) "protection-for-sale" model. To wed the analysis of tariff structure as much as possible with our previous theoretical model, we assume that there are external economies of scale at the national level, as in Wilfred J. Ethier (1982) and Helpman (1984). Since almost all of the setup draws directly from Grossman and Helpman (1994), we proceed with a terse explanation.

There are $n+1$ industries indexed by $i$. Utility is given by $u=q_{0}+\sum_{i=1}^{n} u_{i}\left(q_{i}\right)$. Industries produce homogeneous goods. Let $p_{i}$ be the domestic price of good $i$, let $p_{i}^{*}$ be its world price, and let $\tau_{i}=\left(p_{i}-p_{i}^{*}\right) / p_{i}^{*}$ be the tariff $\left(\tau_{i}<0\right.$ is an export subsidy). Good 0 serves as a numeraire, with a world and domestic price equal to 1 .

Turning to production, one unit of labour produces one unit of $q_{0}$. This implies $w=1$. All other goods are produced with a specific factor and a mobile factor (labor). Output of firm $k$ in industry $i$ is $F_{i}\left(L_{i k}\right) G_{i}\left(L_{i}\right)$ where $L_{i k}$ is the firm's labor input and $L_{i}=\Sigma_{k} L_{i k}$ is industry-level employment. For expositional simplicity alone we assume that $F_{i}=\left(L_{i k}\right)^{\beta_{i}}$ and $G_{i}=\left(L_{i}\right)^{\gamma_{i}}$ where both $\beta_{i}$ and $\gamma_{i}$ lie between 0 and 1. (As show in Appendix $\mathrm{C}$, all we need is $F_{i}^{\prime}>0, F_{i}^{\prime \prime}<0$, and $G_{i}^{\prime}>0$.) Our only departure from the protection-for-sale model is the appearance of $G_{i}$, which captures the external economy. Specifically, in maximizing profits the firm takes $L_{i}$ as fixed. This yields the first-order condition

$$
p_{i} F_{i}^{\prime}\left(L_{i k}\right) G\left(L_{i}\right)=1 \text {. }
$$


We assume that the productivity gains from the externality are never so strong that the tariff reduces industry employment $L_{i}$. A necessary and sufficient condition for this is $\beta_{i}+\gamma_{i}<1 .^{22}$

The industry $i$ lobby group maximizes its welfare $W_{i}(p)$, which is given as the sum of (1) rents in industry $i$, (2) labor income of owners of the specific input used in industry $i$, and (3) a share $\alpha_{i}$ of society's tariff revenue plus consumer surplus, where $\alpha_{i}$ is the fraction of the voting population that owns some of the industry- $i$ specific factor. The industry lobby chooses a contribution schedule that maximizes the difference between the lobby's welfare $W_{i}(p)$ and its contributions.

Government welfare is $a W(p)+C(p)$ where $W(p)=\Sigma_{i} W_{i}(p)$ is welfare summed across all industries (including those that have no organized lobby), $C(p)$ is lobbying contributions, and $a$ captures the weight the government places on gross welfare relative to political contributions. Note that $a W(p)+C(p)$ depends on the externalities $G_{i}\left(L_{i}\right)$. We assume that when the government chooses an optimal tariff it internalizes the externality. That is, it treats the $G_{i}\left(L_{i}\right)$ endogenously. For symmetry, we assume that the lobby also treats $G_{i}\left(L_{i}\right)$ endogenously, though whether it treats it endogenously or exogenously has no qualitative impact on our results.

Let $q_{i}\left(p_{i}\right)$ and $m_{i}\left(p_{i}\right)$ be output and net imports for industry $i$, respectively. Under our assumptions these are functions of own-industry prices only. Let $I_{i}$ be a binary indicator taking on a value of 1 if the industry has an organized lobby and a value of 0 if the industry is not organized. Let $\alpha_{L} \equiv \Sigma_{i \in L} \alpha_{i}$ be the share of voters that own specific factors in organized industries.

When there is no externality $\left(\gamma_{i}=0\right)$, we are in a Grossman and Helpman (1991, 1994) world. They prove that the subgame-prefect Nash equilibrium of the tradepolicy game satisfies

$$
\tau_{i}=\frac{q_{i}\left(p_{i}\right)}{\left[-p_{i}^{*} m_{i}^{\prime}\left(p_{i}\right)\right]} \frac{I_{i}-\alpha_{L}}{a+\alpha_{L}}
$$

where $m_{i}^{\prime} \equiv \partial m_{i} / \partial p_{i}<0$. (See Grossman and Helpman (1994), proposition 2 and footnote 10.) Equation (4) states that industries are protected if and only if they are organized: $\tau_{i}>0 \Leftrightarrow \mathrm{I}_{i}=1$. The equation also states that the highest levels of protection go to industries that are large $\left(q_{i}\right.$ large $)$ and characterized by an inelastic supply of imports $\left(-m_{i}^{\prime}\right.$ small).

Now consider the case where there is an externality. Let $\varepsilon_{i} \equiv d \ln G_{i}\left(L_{i}\right) / d \ln p_{i}$ be the elasticity of the externality with respect to the tariff. A simple calculation shows that $\varepsilon_{i}=\gamma_{i} /\left(1-\beta_{i}-\gamma_{i}\right)>0 .{ }^{23}$

\footnotetext{
22 The proof is as follows. As in Grossman and Helpman (1994), the number of firms $N_{i}$ is exogenous; otherwise, free entry would dissipate all rents and eliminate the motive for protection. Since all firms are identical, $L_{i k}=\mathrm{L}_{i} / N_{i}$. Substituting this into equation (3) and solving for $L_{i}$ yields $L_{i}=\left(p_{i} \beta_{i} N_{i}^{\beta_{i}}\right)^{1 /\left(1-\beta_{i}-\gamma_{i}\right)}$. Hence, $d \ln L_{i} / d \ln p_{i}=1-\beta_{i}-\gamma_{i}$, which we require to be positive.

${ }^{23}$ From the previous footnote, $G_{i}\left(L_{i}\right)=L_{i}^{\gamma_{i}}=\left(p_{i} \beta_{i} N_{i}^{\beta_{i}}\right)^{\gamma_{i} /\left(1-\beta_{i}-\gamma_{i}\right)}$. Hence $d \ln G_{i}\left(L_{i}\right) / d \ln p_{i}=\gamma_{i} /\left(1-\beta_{i}-\gamma_{i}\right)$.
} 
THEOREM 1: The subgame-perfect Nash equilibrium of the trade-policy game satisfies

$$
\tau_{i}=\frac{q_{i}\left(p_{i}\right)}{\left[-p_{i}^{*} m_{i}^{\prime}\left(p_{i}\right)\right]}\left[\frac{I_{i}-\alpha_{L}}{a+\alpha_{L}}+\frac{a+1}{a+\alpha_{L}} \varepsilon_{i}\right]
$$

for $i>0$.

The proof appears in Appendix C.

The equation (5) term involving $\varepsilon_{i}$ is what we have added to Grossman and Helpman (1994). $\varepsilon_{i}$ measures the strength of the externality. The theorem states that industries with large externalities will have large tariffs. This is because both the government and the lobby benefit from the externality. (In the term $a+1$ that multiplies $\varepsilon_{i}, a$ captures the government's benefit and 1 captures the lobby's benefit.) In terms of our empirical work, there is an externality-bias of tariff structure. All else equal, if externalities are greater in skill-intensive industries-a plausible assertion that is backed up empirically by Antweiler and Trefler (2002) — then Theorem 1 states that the tariff structure is skilled-biased.

Theorem 1 also explains why the skill bias of tariffs depends on governance. Good governance is captured by a big $a$, the weight the government puts on welfare net of lobby contributions. Better governance leads to lower tariffs overall. It also leads to a flattening of the tariff schedule, i.e., industries with the largest tariffs $\left(\left|\tau_{i}\right|\right.$ large $)$ see their tariffs shrink to zero. This means that the skill bias of the tariff structure is decreasing in $a$. To see this in the easiest way possible, consider a world in which industry 1 is skill-intensive and industry 2 is unskilled-intensive. Also assume that the skill-intensive industry generates the greater externality: $\varepsilon_{1}>\varepsilon_{2} \geq 0$. Finally, assume that both sectors are organized $\left(I_{i}=1, i=1,2\right)$. In this setting, our $D I F F_{c}$ measure of the skill bias of tariffs becomes DIFF $\equiv \ln \tau_{1}-\ln \tau_{2}$ and it is straightforward to show that

$$
\text { (6) } \begin{aligned}
\frac{\partial D I F F}{\partial a} & =\frac{\partial \ln \tau_{1}}{\partial a}-\frac{\partial \ln \tau_{2}}{\partial a} \\
& =\frac{\left(1-\alpha_{L}\right)}{\left[1-\alpha_{L}+(a+1) \varepsilon_{1}\right]\left[1-\alpha_{L}+(a+1) \varepsilon_{2}\right]}\left(\varepsilon_{1}-\varepsilon_{2}\right)>0
\end{aligned}
$$

That is, the greater the weight the government places on welfare net of contributions, the more skill biased is the tariff structure it chooses. ${ }^{24}$

\footnotetext{
${ }^{24}$ More generally, $\partial^{2} \tau_{i} /\left(\partial \varepsilon_{i} \partial a\right)$ is negative as can be seen by inspection of equation (5). That is, while better governance lowers tariffs on average, better governance lowers tariffs most in industries where rent seeking is strongest (i.e., where externalities are largest). On a separate note, in showing that $\partial^{2} \tau_{i} /\left(\partial \varepsilon_{i} \partial a\right)$ is negative, as well as in calculating the equation (6) derivative, we are holding the $p_{i}$ fixed. Changes in $a$ and $\varepsilon_{i}$ will lead to changes in $p_{i}$ and this will feed back into $\tau_{i}$. However, this feedback must always be of second order. The proof that it is of second order appears in theorem 2.1 of Nathan Nunn and Trefler (2006) for the case of a very closely related model.
} 
In summary, our modified protection-for-sale model shows how the skill bias of tariffs reflects the effectiveness of good governance in putting a lid on rent-seeking and political influence.

\section{The Omitted-Variables Bias Channel}

\section{A. Omitted Governance Variables}

Motivated by our theoretical analysis of endogenous tariff formation, we consider an explanation for the relationship between the skill bias of tariffs and long-term growth that centers on the fact that countries that are able to control rent seeking are also likely to have other growth-promoting governance structures in place, e.g., rule of law, accountability of government, and political stability. Since these aspects of governance are correlated with long-term growth (e.g., Mauro 1995; Hall and Jones 1999; Acemoglu, Johnson, and Robinson 2001), it is possible that part of the correlation of skill-biased tariffs with growth is driven by the correlation of skill-biased tariffs with standard measures of good governance.

We assess this possibility by first examining whether our skill-bias-of-tariff variables are correlated with standard measures of rent seeking, governance, and institutions. For this we use the six composite governance variables from the World Bank's Governance Matters Database (Kaufmann, Kraay, and Mastruzzi 2003). The measures are voice and accountability, political stability and absence of violence, government effectiveness, regulatory quality, rule of law, and control of corruption.

We find that the skill-bias-of-tariff variables are indeed correlated with each of the six measures. As an example, Figure 2 a shows the relationship between $D I F F_{c}^{\text {Low }}$ and the World Bank's control-of-corruption variable. ${ }^{25}$ The correlation is 0.68 . The strong positive relationship with the World Bank measures provides support for the notion that the skill bias of tariffs reflects the underlying absence of rent seeking in the economy.

The endogeneity of tariffs, as outlined in our augmented protection-for-sale model, hinges critically on the assumption that the government is able to set tariffs freely. In recent years, because of multilateral World Trade Organization (WTO) negotiations, countries have less flexibility setting tariffs. This fact presents a potential falsification test for the hypothesis that skill-biased tariffs are determined by $a$ of the protection-for-sale model. When flexibility in setting tariffs is reduced, the political influence mechanism highlighted in the model becomes much less important, and as a result we expect the skill bias of tariffs to be a much worse correlate of domestic rent-seeking pressures.

We test this by repeating Figure 2 a using $D I F F_{c}^{\text {Low }}$ from a later period. We use 2000, the final year in our data. This comes five years after the end of Uruguay round tariff cuts. The relationship between the skill bias of tariffs in 2000 and the World Bank's control of corruption measure is shown in Figure $2 \mathrm{~b} .{ }^{26}$ The relationship is

\footnotetext{
25 The same is true for the other World Bank measures and for the other measures of the skill bias of tariffs. The raw correlations range from 0.50 to 0.72 .

${ }^{26}$ The figure contains the 56 countries in our sample that are WTO members.
} 
Panel A. Initial period skill-bias of tariffs and control of corruption

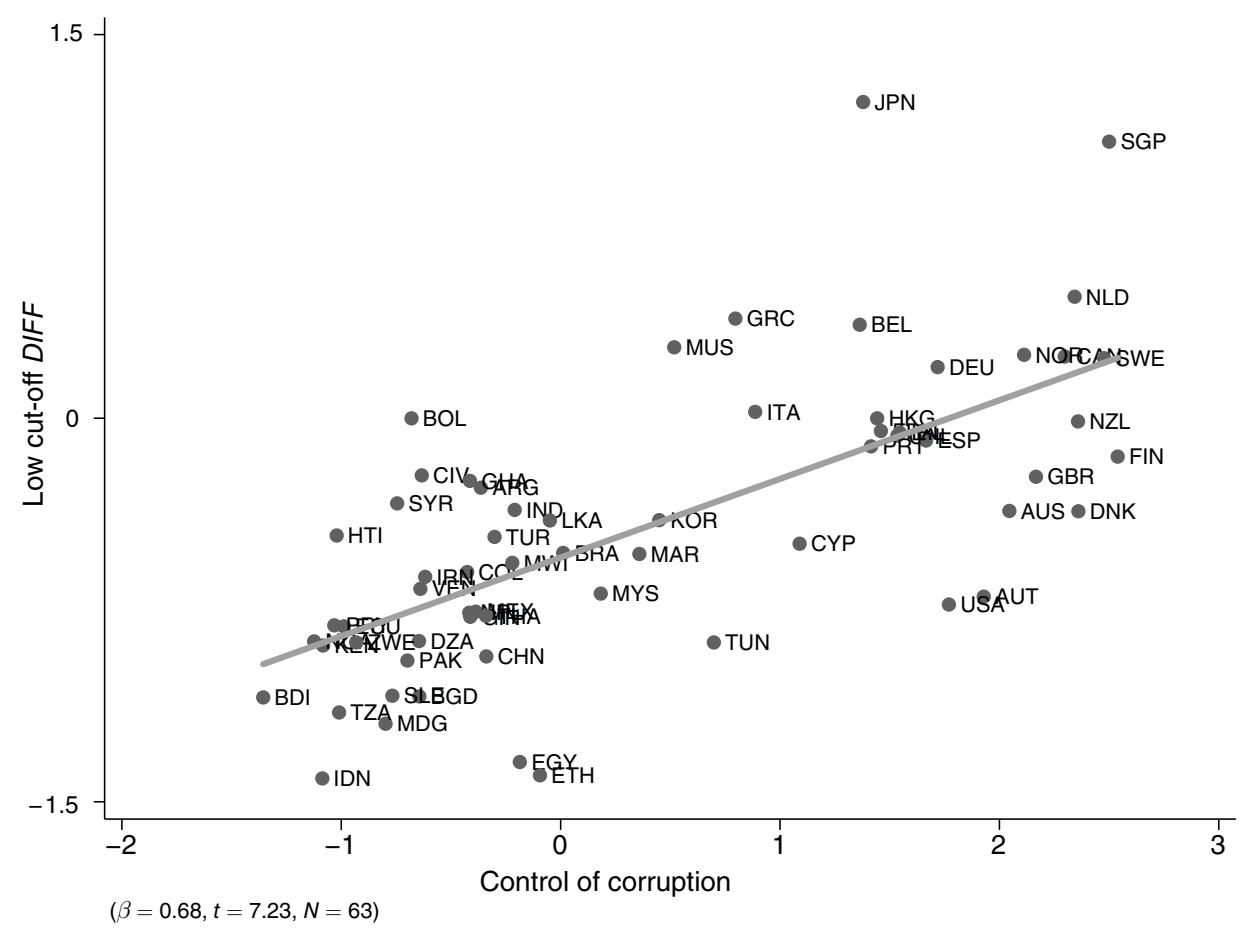

Panel B. Final period skill-bias tariffs and control of corruption

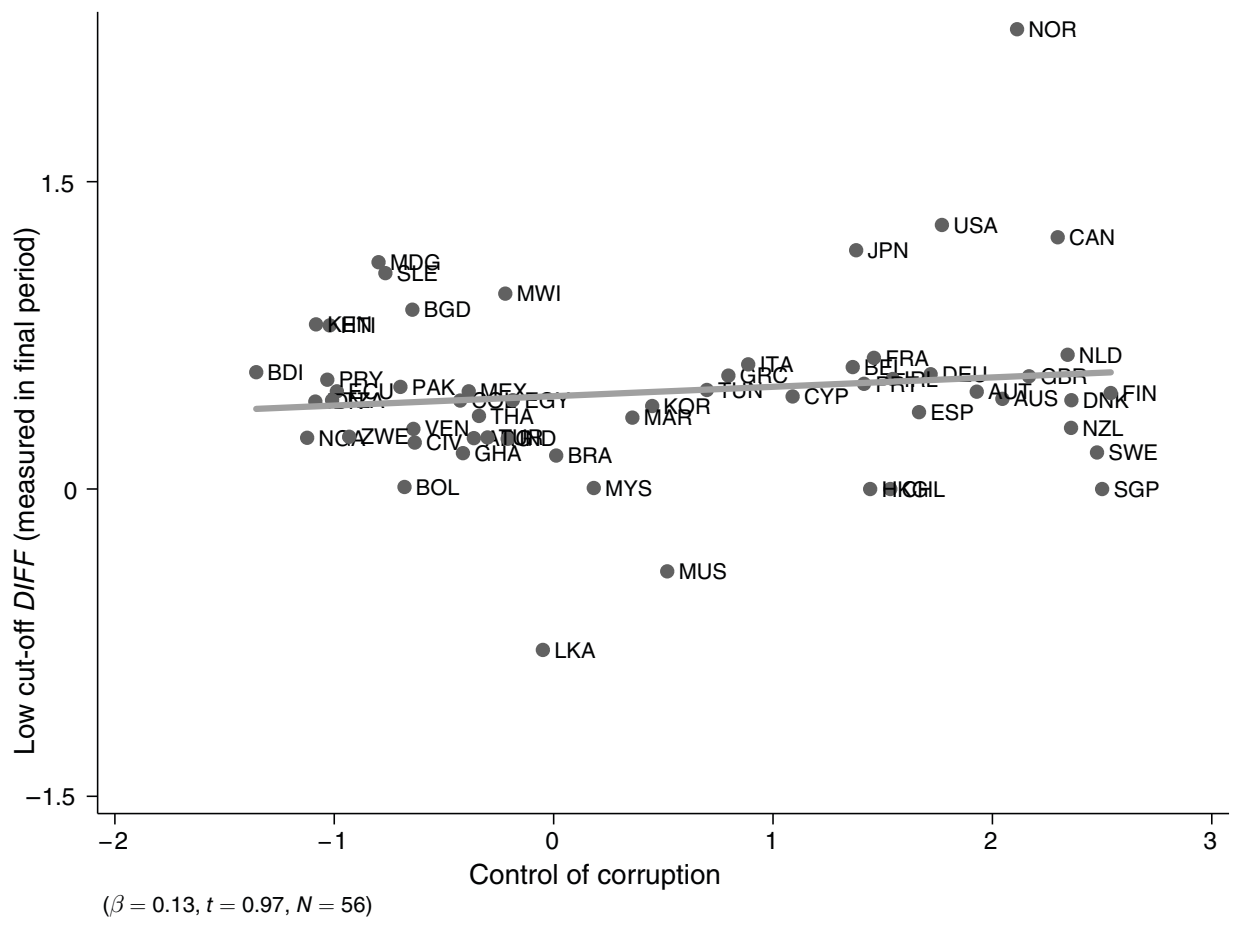

Figure 2. Bivariate RELATIONSHIPS WITH $D I F F_{c}^{\text {Low }}$ 
TABle 10-Governance And Omitted-Variable Bias

\begin{tabular}{|c|c|c|c|c|c|}
\hline & \multicolumn{5}{|c|}{ Dep Var: $\ln y_{c 1} / y_{c 0}$} \\
\hline & \multirow{2}{*}{$\frac{\text { Correlation }}{(1)}$} & \multicolumn{2}{|c|}{ Low cut-off } & \multicolumn{2}{|c|}{ High cut-off } \\
\hline & & (2) & (3) & (4) & (5) \\
\hline \multicolumn{6}{|l|}{ Skill bias of tariff structure } \\
\hline Skill tariff correlation: $\rho_{c}$ & $\begin{array}{c}0.019 \\
(1.96)\end{array}$ & & & & \\
\hline Tariff differential: $D I F F_{c}$ & & $\begin{array}{c}0.010 \\
(2.27)\end{array}$ & & $\begin{array}{c}0.012 \\
(2.88)\end{array}$ & \\
\hline Skilled tariff: $\ln \tau^{\text {Skill }}$ & & & $\begin{array}{c}0.011 \\
(2.41)\end{array}$ & & $\begin{array}{c}0.013 \\
(2.88)\end{array}$ \\
\hline Unskilled tariff: $\ln \tau^{\text {Unskill }}$ & & & $\begin{array}{c}-0.009 \\
(2.21)\end{array}$ & & $\begin{array}{c}-0.010 \\
(2.53)\end{array}$ \\
\hline 6 governance variables & Yes & Yes & Yes & Yes & Yes \\
\hline Average tariffs: $\ln \bar{\tau}_{c 0}$ & Yes & Yes & Yes & Yes & Yes \\
\hline Initial production structure & Yes & Yes & Yes & Yes & Yes \\
\hline 3 country characteristics & Yes & Yes & Yes & Yes & Yes \\
\hline All fixed effects & Yes & Yes & Yes & Yes & Yes \\
\hline$R^{2}$ & 0.82 & 0.82 & 0.82 & 0.84 & 0.83 \\
\hline
\end{tabular}

Notes: This table is identical to Table 4, with one exception. The regressions include six additional regressors i.e., the six World Bank measures of governance.

now much weaker than in Figure 2a. The standardized beta coefficient is 0.13 (compared with 0.68 in Figure 2a), and the relationship is now statistically insignificant (with the $t$-statistic falling from 7.23 to 0.97 ). ${ }^{27}$ This falsification test provides added evidence that the skill-bias-of-tariff measures do in fact reflect the absence of rent seeking in the economy. When tariffs are not determined primarily in the domestic sphere, there is no longer as strong an influence by domestic interest groups, and the skill-bias-of-tariffs measures become much more weakly correlated with measures of domestic rent seeking and governance.

Given evidence that the skill bias of tariffs reflects governance and rent seeking, we re-estimate our baseline equation (2) while controlling for the World Bank's six governance measures. That is, we add all six governance measures to our equation (2) regression. Estimates are reported in Table 10. ${ }^{28}$ With the exception of the new governance variables, the specifications are identical to those in Table 4. Consider the results for our correlation measure of skill-biased tariffs $\rho_{c}$ reported in column 1 . The coefficient on $\rho_{c}$ shrinks (from 0.035 to 0.019 ), but it does not go to zero and remains statistically significant $(t=1.96)$. Our skill-bias measures also remain significant in all the other specifications in Table 10. The coefficient on DIFF ${ }_{c}^{\text {Low }}$ shrinks from 0.016 to $0.010(t=2.27)$ and the coefficient on $D I F F_{c}^{H i g h}$ shrinks from 0.020 to $0.012(t=2.72)$. In each case, the coefficient shrinks by between 37 and 46 percent, but remains statistically significant.

\footnotetext{
${ }^{27}$ The correlation with the other five World Bank measures is also much weaker. The raw correlations with the skill bias of tariffs in 2000 ranges from -0.03 to 0.18 .

${ }^{28}$ The results for the industry-country level regressions are similar.
} 


\section{B. The Skill Bias of Tariffs as an Improved Measure of Rent Seeking?}

We have now examined two possible channels through which growth could be correlated with the skill bias of tariffs. In Section V, we found that the first channel involving growth-promoting impacts of tariffs on industrial structure is able to explain at most 25 percent of the total correlation. The results from the previous section have shown that approximately 35 percent of the correlation can be explained by appeal to the omitted-variables bias channel. We are left with a significant portion, approximately 40 percent of the correlation, unexplained. ${ }^{29}$

There are a number of potential explanations for the remaining portion of the correlation between skill-biased tariffs and growth. One is that our skill bias of tariffs measures are spuriously correlated with other country characteristics that are important for economic growth. However, we feel that this is unlikely. We remind the reader that we have been very careful to control for many initial-period country characteristics, including per capita income, human capital, and investment. We have also included unusually detailed region fixed effects that control for country characteristics such as endowments, geography, and history that are similar within our finely defined regions. It thus seems unlikely that our results are driven by omitted-variable bias associated with such country characteristics.

A particularly compelling possibility is that countries which experienced rapid growth over our period also had large skill-intensive industries initially. If so, the established elites in high-growth countries-owners of skill-intensive industrieswould have lobbied hard for a skill-biased tariff structure. ${ }^{30}$ If initial industrial structure is positively correlated both with subsequent growth and with a skillbiased tariff structure, then there will be a spurious correlation between growth and the skill bias of tariffs. However, from the outset we have been careful to account for this channel by controlling for the initial-period output of skill- and unskilledintensive industries, $q_{c 0}^{\text {Skill }}$ and $q_{c 0}^{\text {Unskill }}$.

The most plausible explanation for the persistent robustness of the correlation between the skill bias of tariffs and growth, is that the skill bias of tariffs provides a better measure of a country's ability to control rent-seeking behavior than standard measures of rent seeking. There are two reasons why this is the case. One deals with measurement error, the other with what is being measured. First, tariff data are objective policy outcomes that are precisely measured. They are based on administrative records that countries must accurately report as part of international treaty obligations. Accuracy is ensured by the fact that export-oriented foreign businesses lodge complaints when there is a discrepancy between the administrative records submitted to the General Agreement on Tariffs (GATT)/WTO, and the customs duties collected locally. Typical measures of the presence of rent seeking are based on subjective

\footnotetext{
${ }^{29}$ We have examined the importance of changing industrial structure and omitted governance variables separately. Examining both effects simultaneously results in the same conclusions. Controlling for both $\Delta \ln q^{\text {Skill }} / q^{\text {Unskill }}$ and the six World Bank measures reduces the coefficient on the skill bias measures by $58-64$ percent, leaving 36-42 percent of the correlation unaccounted for.

${ }^{30}$ This possibility was advanced for example by Eric L. Jones (1988) and Acemoglu, Johnson and Robinson (2005) in arguing that the West grew rich in part because it was lucky to have elites that favored pro-growth policies.
} 
assessments by risk agencies and multinational organizations. Often the underlying data used for these assessments are collected from survey responses of business people where it is unclear whether the respondents care about the accuracy of their responses or whether the set of respondents is representative. Further, because the measures are subjective, they can be influenced by factors not directly related to the variable being measured (see Edward L. Glaser et al. 2004).

Second, our measure captures aspects of rent seeking not captured by standard measures of rent seeking. Although rent-seeking behavior can operate via many channels, standard measures of rent seeking focus on illegal activities. Yet a politician can grab resources through entirely legal and socially acceptable lobbying methods. For example, Colombia's sole Volkswagen dealership managed to have high tariffs erected against all imported autos above a certain weight. This ensured that Volkswagen - the lightest car on the market—had a near monopoly. The dealership was owned by a politician's brother-in-law. This example would not likely show up in any of the familiar measures of rent seeking.

Going through the details of the six World Bank measures, one sees nothing about the legal redistribution of wealth through lobbying and political connections. Yet this is likely a large component, if not the core component, of what the skill bias captures. Contributions in the protection-for-sale model are usually interpreted as legally and socially acceptable influence peddling. For example, both Goldberg and Maggi (1999) and Gawande and Bandyopadhyay (2000) measure influence peddling using publicly recorded political contributions.

Recent studies have begun to identify and measure entirely legal forms of rentseeking behavior. Fisman and Miguel (2007) construct a country-level measure of the willingness of diplomats stationed in Manhattan to engage in a purely legal form of rent seeking. They use the number of accumulated parking violations as an objective measure of a diplomat's use of their diplomatic immunity for their own private gain. Like our measure of the skill bias of tariffs, Fisman and Miguel's (2007) measure objectively captures the presence of a purely legal form of rent seeking. To assess our conjecture that the skill bias of tariffs captures aspects of purely legal rent-seeking behavior, we examine the relationship between DIFF ${ }_{c}^{\text {Low }}$ and Fisman and Miguel's (2007) measure of accumulated parking tickets. As shown in Figure 3 a, there is a clear relationship between the two variables. In countries with diplomats that are more likely to accumulate unpaid parking tickets, tariffs are more biased towards unskilled industries (i.e., the skill bias of tariffs is lower).

In a pair of innovative papers, Mara Faccio (2006) and Faccio, Ronald W. Masulis, and John J. McConnell (2006) quantify political connectedness for 47 countries by looking at the fraction of firms that have large shareholders or top officers that are politically connected. An individual is identified as being politically connected if he or she is a member of parliament, a minister, or closely related to a top politician or political party. ${ }^{31}$ This measure provides an indicator of a form of rent seeking,

\footnotetext{
${ }^{31}$ See also Asim Ijaz Khwaja and Atif Mian (2005) and Hongbin Li, Lingsheng Meng, Quan Wang, and Li-An Zhou (2008), who pursue a similar strategy to identify political connections in Pakistan and China, respectively. Raymond Fisman (2001) quantifies the value of political connections by comparing differences in stock price movements between politically connected and unconnected Indonesian firms in response to reports of President Suharto's failing health between 1995 and 1997.
} 
Panel A. Parking ticket violations

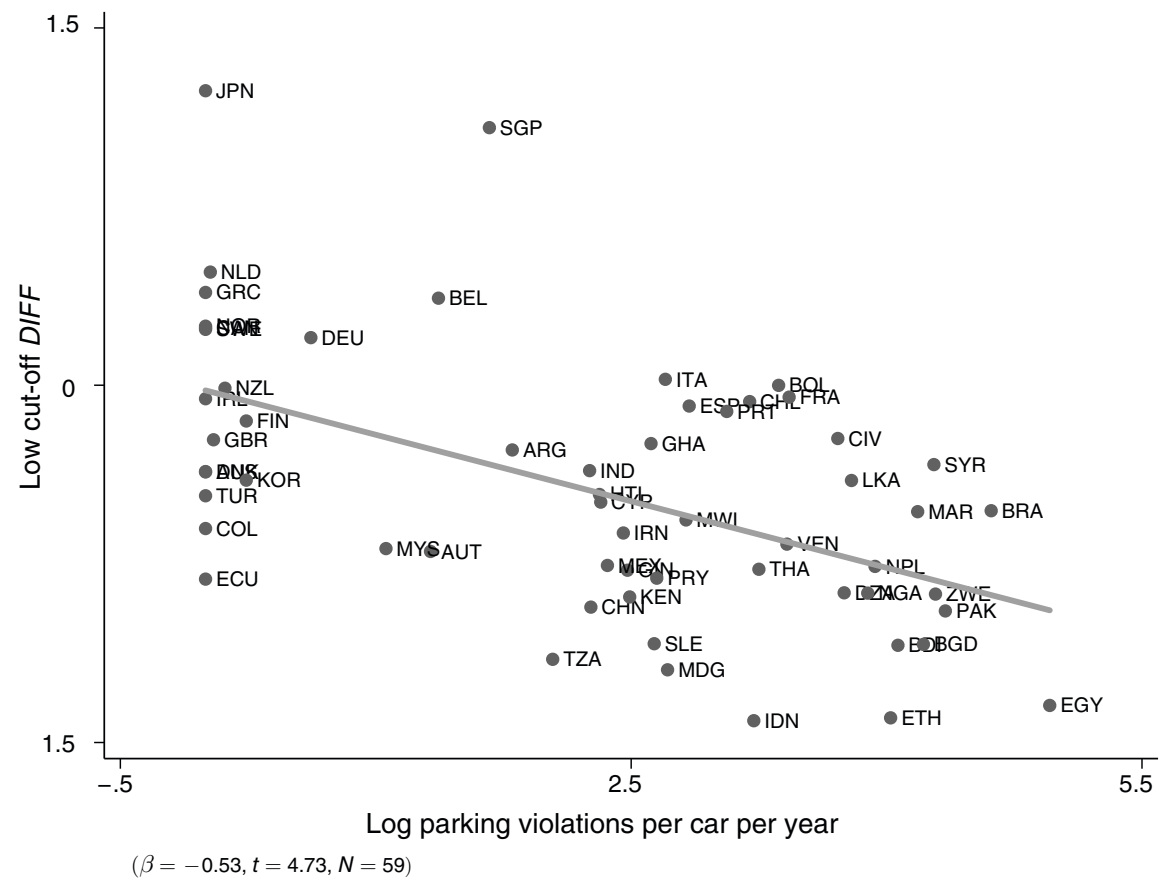

Panel B. Political connectedness

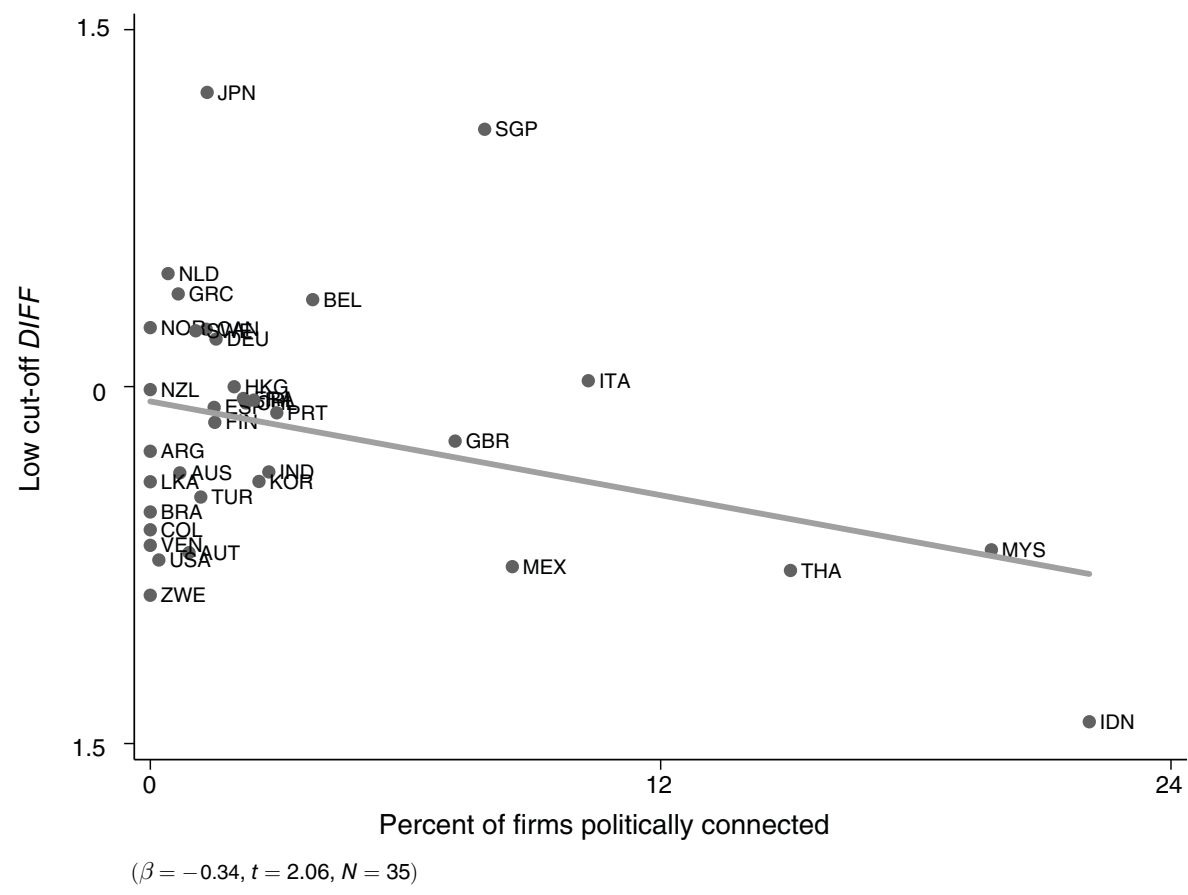

Figure 3. Bivariate ReLationships With DIFF $F_{c}^{\text {Low }}$ 
Table 11-Robustness to the Choice of Skill Intensities and Cut-Offs

\begin{tabular}{|c|c|c|c|c|c|c|}
\hline & \multicolumn{3}{|c|}{ Country regressions } & \multicolumn{3}{|c|}{ Industry-country regressions } \\
\hline & $\begin{array}{c}\text { U.S.A. } \\
\text { (1) }\end{array}$ & $\begin{array}{l}\text { S. Africa } \\
\text { (2) }\end{array}$ & $\begin{array}{l}\text { Brazil } \\
\text { (3) }\end{array}$ & $\begin{array}{c}\text { U.S.A. } \\
\text { (4) }\end{array}$ & $\begin{array}{l}\text { S. Africa } \\
\text { (5) }\end{array}$ & $\begin{array}{c}\text { Brazil } \\
(6)\end{array}$ \\
\hline \multirow[t]{2}{*}{ Cut-off 5} & 0.016 & 0.015 & 0.006 & 0.035 & 0.038 & 0.011 \\
\hline & $(2.96)$ & $(2.75)$ & $(1.21)$ & $(3.46)$ & $(4.08)$ & $(1.20)$ \\
\hline \multirow[t]{2}{*}{ Cut-off 6} & 0.016 & 0.015 & 0.015 & 0.033 & 0.043 & 0.036 \\
\hline & $(2.97)$ & $(2.80)$ & $(3.00)$ & $(3.43)$ & $(4.20)$ & $(3.52)$ \\
\hline \multirow[t]{2}{*}{ Low cut-off } & 0.016 & 0.015 & 0.016 & 0.033 & 0.042 & 0.038 \\
\hline & $(3.29)$ & $(2.75)$ & $(3.63)$ & $(3.43)$ & $(4.00)$ & $(4.07)$ \\
\hline \multirow[t]{2}{*}{ Cut-off 8} & 0.014 & 0.017 & 0.016 & 0.028 & 0.039 & 0.037 \\
\hline & (2.94) & $(3.65)$ & $(3.57)$ & $(3.22)$ & $(3.96)$ & $(3.88)$ \\
\hline \multirow[t]{2}{*}{ Cut-off 9} & 0.013 & 0.014 & 0.014 & 0.030 & 0.030 & 0.029 \\
\hline & $(3.12)$ & $(3.17)$ & $(3.32)$ & $(3.33)$ & $(2.90)$ & $(3.45)$ \\
\hline \multirow[t]{2}{*}{ Cut-off 10} & 0.012 & 0.013 & 0.014 & 0.027 & 0.028 & 0.027 \\
\hline & (3.09) & (2.98) & (3.37) & $(3.25)$ & $(2.66)$ & $(3.27)$ \\
\hline \multirow[t]{2}{*}{ Cut-off 11} & 0.011 & 0.012 & 0.013 & 0.022 & 0.024 & 0.027 \\
\hline & $(2.94)$ & $(2.87)$ & $(3.14)$ & $(2.67)$ & $(2.45)$ & $(3.10)$ \\
\hline \multirow[t]{2}{*}{ Cut-off 12} & 0.005 & 0.010 & 0.012 & 0.010 & 0.017 & 0.025 \\
\hline & $(2.42)$ & $(1.81)$ & $(3.07)$ & $(4.22)$ & $(1.45)$ & $(3.02)$ \\
\hline \multirow[t]{2}{*}{ High cut-off } & 0.020 & 0.010 & 0.010 & 0.039 & 0.016 & 0.020 \\
\hline & $(4.91)$ & $(1.75)$ & $(2.40)$ & $(4.43)$ & $(1.43)$ & $(2.51)$ \\
\hline
\end{tabular}

Notes: Each entry in the table reports the estimated coefficient and $t$-statistic for $D I F F_{c}$ from a single regression. Columns indicate the country whose skill intensity is used to rank industries. Rows indicate the industry $i^{*}$ used as the cut-off in defining $D I F F_{c}$. The country regressions are estimates of equation (1) and use dependent variable $\ln y_{c 1} / y_{c 0}$. See columns 2 and 4 of Table 4 for details of the estimating equation. The industry-country regressions are estimates of equation (2) and use dependent variable $\ln q_{i c 1} / q_{i c 0}$. See columns 2 and 4 of Table 5 for a description of the estimating equation.

through perfectly legal political influence, that is not likely captured by existing measures. Figure $3 \mathrm{~b}$ shows the relationship between $D I F F_{c}^{\text {Low }}$ and the measure of political connections taken from Faccio (2006). Because of limited data on political connections, the sample is reduced to only 35 countries. However, even among the smaller sample one observes a negative relationship.

The possibility that the skill bias of tariffs provides an alternative, and maybe even improved, measure of rent seeking is important. Rent-seeking behavior can be difficult to measure systematically, especially when it involves legal activities that conform to a country's social and political norms. Given the importance of tariff setting as an arena for rent-seeking behavior, the structure of tariffs across countries has the potential to speaks volumes about domestic rent-seeking pressures. We have provided theory and evidence suggesting that the skill bias of tariffs is an objective measure of rent-seeking behavior that has a number of potentially attractive qualities. Unlike existing measures, it captures purely legal and even socially accepted forms of political influence. As well, it is accurately measured and available for nearly all countries going far back in time.

\section{Conclusions}

This paper has been devoted to better understanding the relationship between the structure of tariffs and long-term economic growth. Our first contribution was to document the existence of a strong positive correlation between the skill bias of 
TABle 12-Robustness and SEnSITIVITy AnAlysis.

\begin{tabular}{|c|c|c|c|c|c|c|}
\hline & \multicolumn{3}{|c|}{ Country regressions } & \multicolumn{3}{|c|}{ Industry-country regressions } \\
\hline & $\rho_{c}$ & $D I F F_{c}^{\text {Low }}$ & $D I F F_{c}^{\text {High }}$ & $\rho_{c}$ & $D I F F_{c}^{\text {Low }}$ & $D I F F_{c}^{\text {High }}$ \\
\hline \multirow[t]{3}{*}{ Baseline } & 0.035 & 0.016 & 0.020 & 0.066 & 0.033 & 0.039 \\
\hline & $(3.50)$ & $(3.29)$ & $(4.91)$ & $(3.40)$ & $(3.43)$ & $(4.43)$ \\
\hline & 63 & 63 & 63 & 1,004 & 1,004 & 1,004 \\
\hline \multirow[t]{3}{*}{ Omitting agriculture } & 0.032 & 0.018 & 0.018 & 0.064 & 0.032 & 0.040 \\
\hline & $(3.41)$ & $(3.60)$ & $(3.99)$ & $(4.20)$ & $(3.59)$ & $(4.00)$ \\
\hline & 63 & 63 & 63 & 942 & 942 & 942 \\
\hline Omitting & 0.046 & 0.024 & 0.021 & 0.093 & 0.052 & 0.042 \\
\hline \multirow[t]{2}{*}{10 richest countries } & $(3.81)$ & $(3.77)$ & $(4.49)$ & $(4.70)$ & $(4.00)$ & $(4.40)$ \\
\hline & 53 & 53 & 53 & 826 & 826 & 826 \\
\hline Omitting influential & 0.024 & 0.012 & 0.016 & 0.062 & 0.036 & 0.040 \\
\hline \multirow[t]{2}{*}{ Observations } & $(2.51)$ & $(2.65)$ & $(3.75)$ & (3.32) & (3.91) & (4.90) \\
\hline & 60 & 58 & 58 & 996 & 995 & 995 \\
\hline
\end{tabular}

Notes: Each entry in the table reports the coefficient, $t$-statistic and number of observations from one regression. The country regressions are estimates of equation (1). The dependent variable is the average annual growth of per capita GDP in country $c$. The baseline estimates reproduce columns 1, 2, and 4 of Table 4 . The industry-country regressions are estimates of equation (2). The dependent variable is the average annual growth in output of industry $i$ in country $c$. The baseline estimates reproduce columns 1, 2 and 4 of Table 5. Influential observations are omitted if the Welsch distance is greater than $3 \sqrt{K}$, where $K$ is the number of estimated parameters in the estimating equation.

tariffs and long-term growth. We have shown that the relationship is extremely robust, and its magnitude is large.

We then turned to potential causal mechanisms underlying the relationship. We developed a model showing how initial period tariffs focused in skill-intensive industries could lead to long-term specialization in skill-intensive industries, and increased aggregate growth. We tested for this channel by moving to a panel of industries and countries. We found evidence for this mechanism, but also found that it is only able to explain about 25 percent of the correlation between skill-biased tariffs and aggregate per capita GDP growth. We also examined evidence for mechanisms outside of our model. Looking specifically at potential economy-wide externalities, we tested whether the skill bias of tariffs is associated with an aggregate increase in human capital or knowledge accumulation. We found no evidence for these mechanisms.

We then turned to explanations that involve omitted-variables bias. The skill bias of tariffs may be correlated with standard measures of governance and institutions, which in turn affect growth. Relying on an augmented Grossman and Helpman (1994) protection-for-sale model with positive production externalities in skill-intensive industries, we showed that the model yields a positive correlation between the parameter $a$, the weight the government places on aggregate welfare relative to private contributions, and the skill bias of tariffs. Motivated by the theory, we then controlled for all six World Bank measures of governance in our baseline regressions. We found that the coefficients on the skill-bias-of-tariff variables did indeed shrink (by about 40 percent), but remained large and statistically significant.

Together, the real effects of a skill-biased tariff structure, and the correlation with standard measures of governance and rent seeking, are only able to explain about 60-65 percent of the total correlation. We then discussed the possibility that the 
remaining 35-40 percent is explained by the fact that the skill bias of tariffs captures additional aspects of rent seeking that are not captured by standard measures of governance and institutions. Unlike standard measures, the skill bias of tariffs is an objective measure. Further, it also captures purely legal forms of rent seeking and influence peddling that are omitted form standard measures that focus primarily on illegal forms of rent seeking. We showed that the skill bias of tariffs is highly correlated with two recent objective measures that also capture purely legal forms of rent seeking. These are Fisman and Miguel's (2007) measure of diplomatic parking tickets and Faccio's (2006) measure of political connections.

This opens up the possibility that a country's skill bias of tariffs can be used as a proxy for the absence of rent seeking in an economy. The skill-bias measure has a number of potential advantages over existing measures. It is objective, precisely measured, available for a broad cross-section of countries far back in time, and it also captures purely legal forms of rent seeking that are typically ignored by standard measures that focus on purely illegal activities.

Although this paper does not represent the final word on the importance of tariff structure for long-term growth, we feel that we have made three important contributions to the literature. First, we have shown that the structure of tariffs matter. Second, we provided evidence of a channel working through positive production externalities in skill-intensive industries. But, we also showed that this cannot be the full story. The channel is able to explain at most 25 percent of the total correlation. Finally, we provided theory and empirics showing how the skill bias of tariffs can reflect the extent of rent seeking in the economy. This opens up the possibility that a country's skill bias of tariffs can be used as a proxy for the absence of rent seeking in an economy.

\section{Appendix A. Robustness and Sensitivity Analysis}

Table 11 reports the robustness of our estimates to the choice of different cut-offs and different skill-intensity measures. Columns 1 and 4 report the coefficient on $D I F F_{c}$ for different choices of cut-off $i^{*}{ }^{32}$ In the results reported above, the low cutoff was defined as $i^{*}=7$ and the high cut-off was defined as $i^{*}=13$. Estimates for these cut-offs correspond to columns 2 and 4 of Table 4 , and columns 2 and 4 of the Table 5. ${ }^{33}$ Table 11 also shows results when we rank industries using skill-intensity data from South Africa in 1997 and Brazil in 1986. ${ }^{34}$ Data are from Trevor Alleyne and Arvind Subramanian (2001) and Serge Shikher (2004). The results for different cut-offs $i^{*}$ appear in columns 2, 3, 5, and 6 of Table 11 .

Table 12 shows that the baseline results are robust to a number of additional robustness and sensitivity checks. The first panel reports the baseline estimates for comparison. The second panel reports estimates when agriculture is omitted. The next panel reports estimates omitting the ten richest countries in the sample. The

\footnotetext{
${ }^{32}$ Recall that we defined a cut-off $i^{*}$ such that all industries above $i^{*}$ in Table 3 were classified as skill intensive and all industries below or equal to $i^{*}$ were classified as unskilled intensive.

${ }^{33}$ To avoid results that are driven by just a few industries, we require at least four industries in both the skilled and unskilled groups $\left(4<i^{*}<14\right)$.

${ }^{34}$ These data are only available for manufacturing industries, and therefore we only have 17 , rather than 18 industries, for these measures.
} 
TABle 13-Summary Statistics

\begin{tabular}{|c|c|c|c|c|}
\hline & \multicolumn{2}{|c|}{$\begin{array}{l}\text { Country } \\
\text { regressions }\end{array}$} & \multicolumn{2}{|c|}{$\begin{array}{l}\text { Industry-country } \\
\text { regressions }\end{array}$} \\
\hline & Mean & $\mathrm{SD}$ & Mean & SD \\
\hline \multicolumn{5}{|l|}{ Dependent variables } \\
\hline GDP growth: $\ln y_{c 1} / y_{c 0}$ & 0.018 & 0.019 & & \\
\hline Output growth: $\ln q_{i c 1} / q_{i c 0}$ & & & 0.011 & 0.072 \\
\hline \multicolumn{5}{|l|}{ Tariff Structure } \\
\hline $\begin{array}{l}\text { Skill-tariff correlation: } \rho_{c 0} \\
\text { Low cut-off: }\end{array}$ & -0.28 & 0.25 & -0.28 & 0.25 \\
\hline Skilled tariff: $\ln \tau_{c 0}^{\text {Skill }}$ & -2.09 & 1.32 & -2.12 & 1.35 \\
\hline Unskilled tariff: $\ln \tau_{c 0}^{\text {Unskill }}$ & -1.67 & 1.60 & -1.74 & 1.64 \\
\hline Tariff differential: $D I F F_{c 0}$ & -0.42 & 0.55 & -0.38 & 0.55 \\
\hline Initial output, skilled sector: $\ln q_{c 0}^{\text {Skill }}$ & 22.37 & 2.49 & 22.71 & 2.32 \\
\hline Initial output, unskilled sector: $\ln q_{c 0}^{\text {Unskill }}$ & 23.56 & 1.52 & 23.75 & 1.46 \\
\hline \multicolumn{5}{|l|}{ High cut-off: } \\
\hline Skilled tariff: $\ln \tau_{c 0}^{\text {Skill }}$ & -2.36 & 1.29 & -2.39 & 1.30 \\
\hline Unskilled tariff: $\ln \tau_{c 0}^{\text {Unskill }}$ & -1.72 & 1.49 & -1.79 & 1.52 \\
\hline Tariff differential: $D I F F_{c 0}$ & -0.64 & 0.59 & -0.60 & 0.58 \\
\hline Initial output, skilled sector: $\ln q_{c 0}^{\text {Skill }}$ & 21.68 & 2.34 & 21.99 & 2.18 \\
\hline Initial output, unskilled sector: $\ln q_{c 0}^{\text {Unskill }}$ & 23.81 & 1.65 & 24.02 & 1.57 \\
\hline \multicolumn{5}{|l|}{ Country characteristics } \\
\hline Initial income: $\ln y_{c 0}$ & 8.38 & 1.03 & 8.50 & 0.99 \\
\hline Initial investment: $\ln i n v_{c 0}$ & 2.79 & 0.65 & 2.87 & 0.56 \\
\hline Initial human capital: $\ln h k_{c 0}$ & -2.34 & 1.23 & -2.17 & 1.13 \\
\hline Average tariffs: $\ln \bar{\tau}_{c 0}$ & -1.84 & 1.44 & -1.90 & 1.47 \\
\hline \multicolumn{5}{|l|}{ Industry-country characteristics } \\
\hline Initial industry tariff: $\ln \tau_{i c 0}$ & & & -2.31 & 2.01 \\
\hline Initial industry output: $\ln q_{i c 0}$ & & & 20.05 & 2.63 \\
\hline
\end{tabular}

Note: There are 1,004 observations in the industry-country level output growth regressions and 63 observations in the country level GDP growth regressions.

final panel uses the Welsch distance to identify and omit influential observations from the sample.

\section{ApPendix B. Data APPEndix}

For the 17 manufacturing sectors, initial-period output $q_{i c 0}$ and final-period output $q_{i c 1}$ are from UNIDO's INDSTAT3 2002 production database. The output data were converted from the original 3-digit ISIC classification to our industry classification using the following concordance. For each of the following pairs, the first element is our industry code as given in Table 3 and the second element(s) is a 3-digit ISIC code: $(241,323) ;(243,331) ;(245,321+322) ;(247,332) ;(150,372)$; $(246,361+362+369) ; \quad(220,371) ; \quad(248,324+356) ; \quad(244,341) ; \quad(231,382) ;$ (242,355); (233, 384); (140,353 + 354); (232,383); (211,352); (213,351); (249,385). Because of a lack of final period output data, Guinea, Haiti, Madagascar, and Paraguay are dropped from the industry-country level output growth regressions. For Haiti and Madagascar output data are unavailable after 1988, and for Paraguay output data are unavailable after 1981. However, because output data are available for the initial period, we are able to construct $q_{c 0}^{\text {Skill }}$ and $q_{c 0}^{\text {Unskill }}$, and therefore these countries appear in the country level regressions. (Recall that $q_{c 0}^{\text {Skill }}$ and $q_{c 0}^{\text {Unskill }}$ are 
controls in the country regressions.) For Guinea output data are unavailable for all years. We use Senegal's output data to impute $q_{c 0}^{\text {Skill }}$ and $q_{c 0}^{\text {Unskill }}$ for Guinea, and therefore it also appears in the country-level regressions.

For the agricultural sector (industry 110) initial-period output is from Antweiler and Trefler (2002). It is the sum of industries 010 and 020 in their database. Because their data ends in 1992, to construct the average annual change in output growth we use agricultural output data from the World Bank's World Development Indicators.

Tariff data are from Lai and Trefler (2002) and UNCTAD (1994). $\ln \bar{\tau}_{c 0}$ is the $\log$ of the production-weighted average tariff, and $\ln \tau_{i c 0}$ is the $\log$ of initial-period tariffs. We take logs because a small number of countries, notably Bangladesh and India, have tariffs in some industries that are well in excess of 100 percent. Taking $\operatorname{logs}$ reduces the influence of these rates. However, it does not matter whether we use tariffs or the log of tariffs. ${ }^{35}$ When aggregating tariffs up from the industry level we use 1972 production weights. For Guinea, Sierra Leone, and Haiti, 1972 production data are unavailable. For Guinea and Sierra Leone, we use Senegal's production weights, and for Haiti we use the Dominican Republic's production weights.

Per capita GDP is "rgdpch" from PWT 6.1. ${ }^{36}$ The log initial-year investmentto-GDP ratio $\ln i n v_{c 0}$ is the log of gross investment (private plus public) divided by GDP, measured in percent, from PWT 6.1. The log of initial-year human capital $\ln h k_{c 0}$ is the log of the ratio of workers that completed more than 12 years of education to those that completed less than 12 years of education. Data are from Barro and Lee (1993). Because human capital data are unavailable for Haiti, Guinea, and Sierra Leone, we use human capital measures from countries with similar education levels. For Haiti we use the Dominican Republic and for Guinea and Sierra Leone we use Senegal. In this context note that Haiti and Guinea are only in the countrylevel regressions, not the industry-country level regressions. Human capital data for the final year are from Barro and Lee (2001). Patent data used to construct the average annual change in patents granted are from Jaffe and Trajtenberg (2002). Final period tariff data are from UNCTAD's TRade Analysis and INformation System (TRAINS) database, which has been collected and compiled in Jon Haveman's Ultimate Trade Barrier Catalogue.

The six governance variables are from Kaufmann, Kraay, and Mastruzzi (2003), and are measured in 2000 . The variables range from -2.5 to 2.5 , with a higher number indicating "better" governance. The measure of political connectedness from Faccio (2006) is the percentage of firms that have large shareholders or top officers that are politically connected, where a person is assumed to be politically connected if he or she is a member of parliament, a minister, or closely related to a top

\footnotetext{
${ }^{35}$ Hong Kong is the only country with zero tariffs in any industry. In fact, it has zero tariffs in all industries. This means that for Hong Kong $\rho_{c}=D I F F_{c}^{\text {Low }}=D I F F_{c}^{\text {High }}=\bar{\tau}_{c 0}=0$. When taking the log of the average tariff $\bar{\tau}_{c 0}$ and the own-industry tariffs $\tau_{i c 0}$ for Hong Kong (i.e., the $\log$ of 0 ), we set the value to 0.0001 (i.e., 0.01 percent). Our results are not sensitive to adjusting this value up or down.

${ }^{36}$ The unification of East Germany and West Germany in 1990 is handled as follows. For 1991 and 1992 , the PWT 6.1 provides income data for unified Germany, and for East Germany and West Germany separately. We use this data to scale down unified Germany's per capita income so that it matches per capita income for West Germany in 1991 and 1992. The result of this procedure is that Germany's average annual growth of per capita GDP is derived from the income growth for West Germany before 1991 and the income growth of unified Germany after 1991.
} 
politician or political party. The parking tickets measure from Fisman and Miguel (2007) is the natural log of the total number of parking tickets accumulated by a country's diplomats stationed in Manhattan, normalized by the number of vehicles.

Table 13 provides summary statistics of our data.

\section{Appendix C. Protection-for-Sale Proofs}

\section{A. Preliminaries}

In this Appendix we will not make any functional-form assumptions on the $F_{i}$ and $G_{i}$ other than $F_{i}^{\prime}>0, F_{i}^{\prime \prime}<0$ and $G_{i}^{\prime}>0$. In the main text we assumed $d \ln L_{i} / d \ln p_{i}>0$. The following lemma draws out two implications of this assumption.

LEMMA 1: The following three statements are equivalent: (1) $d \ln L_{i} / d \ln p_{i}>0$, (2) $F_{i}^{\prime}\left(L_{i} / N_{i}\right) G_{i}\left(L_{i}\right)$ is decreasing in $L_{i}$, and (3) $\varepsilon_{i}\left(p_{i}\right) \equiv d \ln G_{i}\left(L_{i}\right) / d \ln p_{i}>0$.

The proof is as follows. As in Grossman and Helpman (1994), the number of firms $N_{i}$ is exogenous; otherwise, free entry would dissipate all rents and eliminate the motive for protection. Since all firms are identical, $L_{i k}=L_{i} / N_{i}$. Substituting this into equation (3) to obtain $p_{i} F_{i}^{\prime}\left(L_{i} / N_{i}\right) G_{i}\left(L_{i}\right)=1$ and differentiating establishes the equivalence of parts (1) and (2) of the lemma. From the definition of $\varepsilon_{i}$, $\varepsilon_{i}=\left[d \ln G_{i} / d \ln L_{i}\right]\left[d \ln L_{i} / d \ln p_{i}\right]=\left[G_{i}^{\prime} L_{i} / G_{i}\right]\left[d \ln L_{i} / d \ln p_{i}\right]>0$. This establishes the equivalence of parts (1) and (3).

The equivalence of parts (1) and (2) shows that we can replace the assumption $d \ln L_{i} / d \ln p_{i}>0$ with an assumption on the primitives $F_{i}$ and $G_{i}$. The equivalence of parts (1) and (3) shows that $\varepsilon_{i}>0$.

\section{PROOF OF THEOREM 1}

Let equation $(\mathrm{GH} n)$ be a shorthand for denoting equation $(n)$ in Grossman and Helpman (1994). Our only departure from the Grossman-Helpman exposition is in the treatment of $\partial \pi_{i} / \partial p_{j}$. Industry profit $\pi_{i}$ is $N_{i}$ times firm profit: $\pi_{i}=p_{i} N_{i} F_{i}\left(L_{i} / N_{i}\right)$ $\times G_{i}\left(L_{i}\right)-L_{i}$ where we have used $w=1$. Note that $q_{i}=N_{i} F_{i} G_{i}$. Hence,

$$
\begin{aligned}
\frac{\partial \pi_{i}}{\partial p_{i}} & =q_{i}+N_{i}\left[p_{i} F_{i}^{\prime} G_{i}-1\right] \frac{\partial L_{i} / N_{i}}{\partial p_{i}}+p_{i} N_{i} F_{i} \frac{\partial G_{i}\left(L_{i}\left(p_{i}\right)\right)}{\partial p_{i}} \\
& =q_{i}+\left[N_{i} F_{i} G_{i}\right]\left[\frac{p_{i}}{G_{i}} \frac{\partial G_{i}}{\partial p_{i}}\right]=q_{i}+q_{i} \varepsilon_{i}
\end{aligned}
$$

where the second equality follows from Sheppard's lemma (i.e., the first-order condition equation 3) and the last follows from the definition of $\varepsilon_{i} \equiv \partial \ln G_{i} / \partial \ln p_{i}$. Note that in $\partial \pi_{i} / \partial p_{i}=q_{i}+q_{i} \varepsilon_{i}$, the term $q_{i}$ appears in Grossman and Helpman (1994) and the term $q_{i} \varepsilon_{i}$ is new. All other aspects of the Grossman-Helpman model remain unchanged. 
It follows that equation (GH14), which comes from the lobby's optimization problem, continues to hold with only a slight modification:

$$
\sum_{i \in L} \frac{\partial W_{i}}{\partial p_{j}}=\left(I_{j}-\alpha_{L}\right) q_{j}\left(p_{j}\right)+\alpha_{L}\left(p_{j}-p_{j}^{*}\right) m_{j}^{\prime}\left(p_{j}\right)+q_{i}\left(p_{i}\right) \varepsilon_{i}\left(p_{i}\right)
$$

It also follows that equation (GH15), which comes from the government's optimization problem, continues to hold with only a slight modification:

$$
\frac{\partial W}{\partial p_{j}}=\left(p_{j}-p_{j}^{*}\right) m_{j}^{\prime}\left(p_{j}\right)+q_{j}\left(p_{j}\right) \varepsilon_{j}\left(p_{j}\right)
$$

Following Goldberg and Maggi (1999), the government's problem of maximizing welfare net of contributions is equivalent tomaximizing $\Omega(p ; a) \equiv a W(p)+\Sigma_{i \in L} W_{i}(p)$ with respect to $p=\left(p_{1}, \ldots, p_{n}\right)$ using the derivatives in equations (A2)-(A3):

$$
\begin{aligned}
\frac{\partial \Omega}{\partial p_{j}}= & \left(I_{j}-\alpha_{L}\right) q_{j}\left(p_{j}\right)+\left(a+\alpha_{L}\right)\left(p_{j}-p_{j}^{*}\right) m_{j}^{\prime}\left(p_{j}\right) \\
& +(a+1) q_{j}\left(p_{j}\right) \varepsilon_{j}\left(p_{j}\right) .
\end{aligned}
$$

Substituting in the definition of the tariff as $\tau_{j}=\left(p_{j}-p_{j}^{*}\right) / p_{j}^{*}$ and simplifying yields equation (5) of Theorem 1.

\section{REFERENCES}

Acemoglu, Daron, Simon Johnson, and James A. Robinson. 2001. "The Colonial Origins of Comparative Development: An Empirical Investigation.” American Economic Review, 91(5): 1369-1401.

-Acemoglu, Daron, Simon Johnson, and James Robinson. 2005. "The Rise of Europe: Atlantic Trade, Institutional Change, and Economic Growth.” American Economic Review, 95(3): 546-79.

Alleyne, Trevor, and Arvind Subramanian. 2001. "What Does South Africa's Pattern of Trade Say About Its Labor Market?” International Monetary Fund Working Paper WP/01/148.

-Antweiler, Werner, and Daniel Trefler. 2002. "Increasing Returns and All That: A View from Trade." American Economic Review, 92(1): 93-119.

-Barro, Robert J., and Jong-Wha Lee. 1993. "International Comparisons of Educational Attainment." Journal of Monetary Economics, 32(3): 363-94.

-Barro, Robert J., and Jong-Wha Lee. 2001. "International Data on Educational Attainment: Updates and Implications." Oxford Economic Papers, 53(3): 541-63.

-Clemens, Michael A., and Jeffrey G. Williamson. 2004. "Why Did the Tariff-Growth Correlation Change after 1950?" Journal of Economic Growth, 9(1): 5-46.

DeJong, David N., and Marla Ripoll. 2006. "Tariffs and Growth: An Empirical Exploration of Contingent Relationships." Review of Economics and Statistics, 88(4): 625-40.

-Easterly, William, Michael Kremer, Lant Pritchett, and Lawrence H. Summers. 1993. "Good Policy or Good Luck? Country Growth Performance and Temporary Shocks." Journal of Monetary Economics, 32(3): 459-83.

-Edwards, Sebastian. 1992. "Trade Orientation, Distortions and Growth in Developing Countries." Journal of Development Economics, 39(1): 31-57.

-Edwards, Sebastian. 1998. “Openness, Productivity and Growth: What Do We Really Know?" Economic Journal, 108(447): 383-98.

-Ethier, Wilfred J. 1982. "Decreasing Costs in International Trade and Frank Graham's Argument for Protection." Econometrica, 50(5): 1243-68.

-Faccio, Mara. 2006. "Politically Connected Firms." American Economic Review, 96(1): 369-86. 
Faccio, Mara, Ronald W. Masulis, and John J. McConnell. 2006. "Political Connections and Corporate Bailouts." Journal of Finance, 61(6): 2597-2635.

-Fisman, Raymond. 2001. "Estimating the Value of Political Connections." American Economic Review, 91(4): 1095-1102.

-Fisman, Raymond, and Edward Miguel. 2007. "Corruption, Norms, and Legal Enforcement: Evidence from Diplomatic Parking Tickets." Journal of Political Economy, 115(6): 1020-48.

Fujita, Masahisa, Paul Krugman, and Anthony J. Venables. 2001. The Spatial Economy: Cities,

Regions, and International Trade. Cambridge, MA: MIT Press.

-Gawande, Kishore, and Usree Bandyopadhyay. 2000. "Is Protection for Sale? Evidence on the Grossman-Helpman Theory of Endogenous Protection." Review of Economics and Statistics, 82(1): $139-52$.

-Glaeser, Edward L., Rafael La Porta, Florencio Lopez-de-Silanes, and Andrei Shleifer. 2004. "Do Institutions Cause Growth?” Journal of Economic Growth, 9(3): 271-303.

- Goldberg, Pinelopi Koujianou, and Giovanni Maggi. 1999. "Protection for Sale: An Empirical Investigation." American Economic Review, 89(5): 1135-55.

Grossman, Gene M., and Elhanan Helpman. 1991. Innovation and Growth in the Global Economy. Cambridge, MA: MIT Press.

Grossman, Gene M., and Elhanan Helpman. 1994. "Protection for Sale." American Economic Review, 84(4): 833-50.

Hall, Robert E., and Charles I. Jones. 1999. "Why Do Some Countries Produce So Much More Output Per Worker Than Others?" Quarterly Journal of Economics, 114(1): 83-116.

Helpman, Elhanan. 1984. "Increasing Returns, Imperfect Markets, and Trade Theory." In Handbook of International Economics. Vol. 1, ed. Ronald W. Jones and Peter Kenen, 325-65. Amsterdam: North-Holland.

-Irwin, Douglas A. 2002. "Interpreting the Tariff-Growth Correlation of the Late 19th Century." American Economic Review, 92(2): 165-69.

-Jacks, David S. 2006. "New Results on the Tariff-Growth Paradox." European Review of Economic History, 10(2): 205-30.

Jaffe, Adam B., and Manuel Trajtenberg. 2002. Patents, Citations, and Innovations: A Window on the Knowledge Economy. Cambridge, MA: MIT Press.

Jones, Eric L. 1988. Growth Recurring: Economic Change in World History. Ann Arbor: University of Michigan Press.

Kaufmann, Daniel, Aart Kraay, and Massimo Mastruzzi. 2003. "Governance Matters III: Governance Indicators for 1996-2002.” World Bank Policy Research Working Paper 3106.

-Khwaja, Asim Ijaz, and Atif Mian. 2005. "Do Lenders Favor Politically Connected Firms? Rent Provision in an Emerging Financial Market." Quarterly Journal of Economics, 120(4): 1371-1411.

Krugman, Paul. 1987. "The Narrow Moving Band, the Dutch Disease, and the Competitive Consequences of Mrs. Thatcher: Notes on Trade in the Presence of Dynamic Scale Economies." Journal of Development Economics, 27(1-2): 41-55.

Lai, Huiwen, and Daniel Trefler. 2002. "The Gains from Trade with Monopolistic Competition: Specification, Estimation, and Mis-Specification." National Bureau of Economic Research Working Paper 9169.

Li, Hongbin, Lingsheng Meng, Qian Wang, and Li-An Zhou. 2008. "Political Connections, Financing and Firm Performance: Evidence from Chinese Private Firms." Journal of Development Economics, 87(2): 283-99.

Lucas, Robert E., Jr. 1988. "On the Mechanics of Economic Development." Journal of Monetary Economics, 22(1): 3-42.

Mauro, Paolo. 1995. "Corruption and Growth." Quarterly Journal of Economics, 110(3): 681-712.

Nunn, Nathan, and Daniel Trefler. 2006. "Putting the Lid on Lobbying: Tariff Structure and LongTerm Growth when Protection is for Sale.” National Bureau of Economic Research Working Paper 12164.

-O'Rourke, Kevin H. 2000. "Tariffs and Growth in the Late 19th Century." Economic Journal, 110(463): 456-83.

Rivera-Batiz, Luis A., and Paul M. Romer. 1991. "Economic Integration and Endogenous Growth." Quarterly Journal of Economics, 106(2): 531-55.

Rodriguez, Francisco, and Dani Rodrik. 2001. "Trade Policy and Economic Growth: A Skeptic's Guide to the Cross-National Evidence." In NBER Macroeconomics Annual 2000, ed. Ben S. Bernanke and Kenneth Rogoff, 261-325. Cambridge, MA: MIT Press.

Rodrik, Dani. 2005. "Why We Learn Nothing from Regressing Economic Growth on Policies.” http:// www.hks.harvard.edu/fs/drodrik/Research\%20papers/policy\%20regressions.pdf. 
Rosenberg, Nathan, ed. 1982. "Technological Interdependence in the American Economy." In Inside the Black Box: Technology and Economics, 55-80. Cambridge, UK: Cambridge University Press.

Sachs, Jeffrey D., and Andrew Warner. 1995. "Economic Reform and the Process of Global Integration.” In Brookings Papers on Economic Activity 1995, Vol. 1, ed. George L. Perry and William C. Brainard, 1-118. Washington, DC: Brookings Institution Press.

Shikher, Serge. 2004. "An Improved Measure of Industry Value Added and Factor Shares: Description of a New Dataset of the U.S. and Brazilian Manufacturing Industries." http://web.cas.suffolk. edu/faculty/shikher/papers/Shikher_USBRdata.pdf.

United Nations Conference on Trade and Development (UNCTAD). 1994. Directory of Import Regimes. New York: United Nations.

United Nations Industrial Development Organization (UNIDO). 2003. "UNIDO Industrial Statistics Database in Revision 2 of ISIC: Methodology Notes.” United Nations Development Organization.

-Vamvakidis, Athanasios. 2002. "How Robust Is the Growth-Openness Connection? Historical Evidence." Journal of Economic Growth, 7(1): 57-80.

Yanikkaya, Halit. 2003. "Trade Openness and Economic Growth: A Cross-Country Empirical Investigation.” Journal of Development Economics, 72(1): 57-89. 